
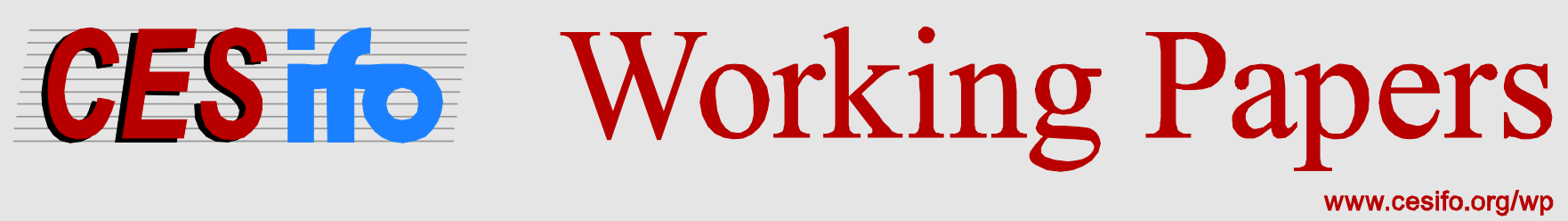

\title{
Business Decision-Making under Uncertainty: Evidence from Employment and Number of Businesses
}

\author{
Vivek Ghosal \\ Yang Ye
}

CESIFO WORKING PAPER NO. 4312

CATEGORY 11: INDUSTRIAL ORGANISATION

JUNE 2013

Presented at CESifo Area Conference on Applied Microeconomics, March 2013

An electronic version of the paper may be downloaded

- from the SSRN website:

- from the RePEc website:

- from the CESifo website:

WWW.SSRN.com

www.RePEc.org

www.CESifo-group.org/wp

\section{CESifo}




\title{
Business Decision-Making under Uncertainty: Evidence from Employment and Number of Businesses
}

\begin{abstract}
Using the framework provided by the asymmetric-information and real-options theories, we examine the impact of uncertainty on firms' decisions and market outcomes. We construct alternative measures of uncertainty based on survey of professional forecasters and our estimation of regression-based forecasting models for GDP growth, inflation, S\&P500 stock price index, and fuel prices. Our results indicate that greater uncertainty has a negative impact on growth of employment and the number of businesses, and the effects are primarily felt by relatively smaller businesses. The impact on large businesses are generally non-existent or weaker. Our results suggest that to truly understand the effects of uncertainty on firms' decisions, we need to focus on the relatively smaller and entrepreneurial businesses. We discuss some implications for framing of policy.
\end{abstract}

JEL-Code: L110, D800, O300, G100, L400.

Keywords: uncertainty, small businesses, entrepreneurship, employment, number of businesses, financing-constraints, real-options.

\author{
Vivek Ghosal \\ School of Economics \\ Georgia Institute of Technology \\ Atlanta / Georgia / USA \\ vivek.ghosal@econ.gatech.edu
}

\author{
Yang Ye \\ Whitman School of Management \\ Syracuse University \\ Syracuse / New York / USA
}

June 7, 2013

Part of this work was conducted when I was a Visiting Scholar at the Research Department of the International Monetary Fund (Washington, D.C.). I benefited from valuable discussions with Prakash Loungani. I am indebted to Christian Gollier and Pierre-André Chiappori for insightful comments on an earlier version of this paper, and to the seminar participants at Mizuho Research Institute (Tokyo), the Development Bank of Japan (Tokyo) and the Center for Economic Studies (Munich) for feedback. 


\section{Introduction}

Theory identifies alternative channels via which uncertainty may affect firms' strategic decisions related to capital outlays, entry, exit, employment, production and choice of technology. The broad classes of theories include: (1) information-asymmetries between borrowers and lenders which, under greater uncertainty, may affect the flow of credit to specific categories of businesses (e.g., Greenwald and Stiglitz, 1990); (2) real-options and the irreversibility of capital expenditures which posit a delaying strategy by businesses when confronted with greater uncertainty (e.g., Dixit and Pindyck, 1994); (3) businesses' attitudes towards risk, with greater risk-aversion dampening a range of strategic decisions (e.g., Appelbaum and Katz, 1986; Hartman, 1976); and (4) the convexity of the marginal-product of capital function (e.g., Abel, 1983). The first three channels tend to predict a negative effect of uncertainty on firms' key decision variables. The fourth channel predicts a positive effect. While a large number of papers have presented the core theory models and their refinements, in this paper we focus on the information-asymmetries and real-options channels as these appear important to gaining insights into firms' strategic and intertemporal decision-making under uncertainty.

There is a considerable empirical literature that has examined how uncertainty affects firms' strategic decisions and market outcomes. The literature highlights the different types of businesses that appear to be affected, and offers some insights into the possible reasons for the differential effects. The broader empirical literature reveals that the estimated effects of uncertainty and qualitative inferences vary considerably across the studies and the particular decision variable under consideration (investment, entry, production, among others). In section 3 we discuss the empirical literature in a bit more detail.

In this paper we use data on U.S. businesses to examine the effects of uncertainty on growth of employment and number of businesses. While there is a significant literature in strategic management, entrepreneurship and economics that has examined the impact of uncertainty on various aspects of firms' strategic decision-making and key choice variables, we are not aware of any systematic study which has examined the uncertainty-employment link, and focused on small businesses in particular. As we note below, given the importance of the small and entrepreneurial businesses in the economy, examining the effects of uncertainty on their employment and number of businesses may be important to understanding the true effects of 
uncertainty on firms' strategic decisions and market outcomes, as well as implications for the study of business cycles and framing of policy. In the ongoing financial crisis, the inability of the small businesses and entrepreneurial sector to start growing rapidly was been noted as a distinctive concern for business and economic growth in coming years.

Our focus on small businesses is motivated by several key factors. First, small businesses play an important role in the economy in several dimensions. The U.S. Small Business Administration (henceforth, SBA) defines a small business as an independent business having fewer than 500 employees. According to the SBA, small businesses represent about 99 percent of all employer firms, and employ about one-half of all private sector employees. Small businesses pay about 43 percent of total U.S. private payroll and have generated 65 percent of net new jobs over the past 18 years. Small businesses create more than half of the non-farm private GDP, made up 97 percent of all identified exporters and produced 31 percent of export value in 2008. Small businesses are also important to U.S. technology improvement. According to the SBA, small businesses hire over 40 percent of high tech workers (scientists, engineers, computer programmers, and others). Finally, small businesses generate patents more efficiently than large firms: they produce 16 times more patents per employee than large patenting firms. Irrespective of the specific dimension under consideration, small businesses play a vital role in the economy.

The importance of small businesses is a global phenomenon. As noted in ACCA (2010) and di Giovanni et al. (2010), the vast majority of businesses globally are very small. They note that small businesses are special because they have several important characteristics: they contribute disproportionately to local economic growth by improving innovation ability; increase job opportunities; and contribute significant tax revenues. Given these attributes, it has become commonplace in the aftermath of the current global economic crisis to refer to SMEs as the backbone of the global economy.

Second, there is a significant literature on entrepreneurship which notes the similarities and differences between small business and entrepreneurship in dimensions related to growth and innovation. Some scholars have characterized a small business as a firm that is not dominant in its field, and engages in relatively less innovative practices. In contrast, an entrepreneurial venture is viewed to be a business whose primary goals are growth and profitability, and characterized by strategic and innovative practices. Carland et al. (1984) and Katz and Green (2010), for example, present a discussion of these issues. In terms of innovation, this literature 
notes that small businesses may sell goods and services which other firms also provide, whereas entrepreneurial businesses are characterized by novelty, in their products, services, or business models. In terms of growth, an entrepreneurial firm may begin at any size level, but key on growth over time, while many small businesses tend to remain small for long periods. Although there are differences in how scholars in Management and Economics view small businesses versus entrepreneurial ventures, in reality there is common ground in many areas and it is relatively difficult to clearly distinguish between them. The literature, therefore, often uses a broad definition of a Small Entrepreneurial Business - anyone who owns a business is an entrepreneur, which suggests anyone who is a small business owner is an entrepreneur. Our examination of the effects of uncertainty on small businesses, therefore, also sheds light on the effects on entrepreneurial ventures.

Third, while the empirical literature on uncertainty is quite extensive, there have been relatively few studies that have distinctly emphasized the effects of uncertainty on the economic activity of small businesses. Examining this link is important, given the structural significance of small business in the economy, and during economic expansions and contractions. Those papers that have focused on the uncertainty-small business effects, have tended to be related to investment (e.g., Ghosal and Loungani, 2000). Our primary focus is on the uncertaintyemployment link, along with the impact on the number of businesses, and the potential distinction between the effects on small versus large businesses. Examining the effects of uncertainty on employment and creation and survival of businesses is important as it has taken on a larger than life significance following the 2007 onwards economic crisis, as well as past crises, where employment effects have taken center stage in policy debates on how to improve economic conditions.

Against this backdrop, we examine the effects of uncertainty, focusing on potential differences between small versus large businesses. Our data on small businesses obtained from the SBA are U.S.-wide, including all small, medium and large businesses in the U.S. Since the data are designed to portray a broader economy-wide picture, our uncertainty measures are constructed using economy-wide variables related to GDP, industrial production, inflation, stock prices, and fuel prices.

In section 2 we note the central results from theory, and present the key hypotheses. Section 3 presents a brief overview of the empirical literature. Data sources and variables are 
discussed in section 4, and in section 5 we outline construction of our measures of uncertainty. Sections 6 and 7 describe the empirical specification we estimate, and present the results. Our findings are that uncertainty negatively affects the growth of employment and the number of businesses, and this impact appears to be concentrated primarily in the relatively smaller business category. The impact on large businesses is either non-existent or quantitatively smaller. Section 8 concludes with a discussion of our findings and some policy issues.

\section{Theoretical literature on the effects of uncertainty}

We focus on two channels when examining the effects of uncertainty. First relates to asymmetric-information and agency problems in borrower-lender relationships. Examining the implications of this channel is particularly important due to our focus on smaller businesses. Second relates to real-options, which has become the mainstay of much of the contemporary literature on examining the effects of uncertainty.

A significant portion of this literature has posed the problem as one of firms' investment decisions under uncertainty. But the broader literature has also examined the complementary issues related to production, technology choices, among other variables. In our discussion below we first detail the entry and investment problems, and then note the implications for employment and number of businesses. Below we review the key results in the theoretical literature, and spell out the hypotheses for our empirical analysis. ${ }^{3}$

\subsection{Uncertainty and information asymmetries}

Information asymmetry between borrowers and lenders may constrain the flow of credit. In an influential paper, Greenwald and Stiglitz (1990) model firms as maximizing expected equity minus expected cost of bankruptcy and examine scenarios where firms may be equity or borrowing constrained. A key result is that greater uncertainty exacerbates information asymmetries, tightens financing constraints and lowers capital outlays. Since uncertainty increases the risk of bankruptcy, firms cannot issue equity to absorb the risk. Those relying primarily on credit and operating outside of equity markets, find the flow of credit rationed. Delli

\footnotetext{
${ }^{3}$ As noted in the introduction, the broader literature on uncertainty is rather extensive, covering issues related to risk-aversion (Appelbaum and Katz, 1986; Hartman, 1976), convexity of the marginal-profit function of capital (Abel, 1983), consumption-based capital asset pricing model (Lucas, 1976), among others. Due to the current emphasis of the literature on the two channels we consider below, and to keep the issues focused, we do not provide elaborate details of all the different theoretical models that have been written in the literature.
} 
Gatti et al. (2003) extend the Greenwald and Stiglitz framework and develop a model in which the financial conditions of businesses affect capital accumulation and entry and exit which affect the distribution of firms differentiated by the equity ratio. In their model flow of exiting firms is endogenously determined through bankruptcy while the flow of entering firms is affected by stochastic factors. Lensink, Bo and Sterken (2001) provide a lucid discussion of credit market conditions in the general context of investment behavior, including the roles played by uncertainty and sunk costs.

This literature shows that periods of greater uncertainty widens the information asymmetry, increases the likelihood of bankruptcy and exacerbates financing constraints. Incumbent businesses who are more dependent on borrowing and adversely affected by tighter credit will have greater likelihood of exit. Similarly, entry is likely to be impeded for potential entrants who are more adversely affected by tighter credit conditions. Thus, periods of greater uncertainty are expected to accelerate exits and retard entry leading to negative net entry - that is, a decline in the number of firms in an industry.

Similar results hold if we examine physical capital investment or employment. Considering employment, periods of greater uncertainty, by constraining credit flows, limit the ability of existing firms to hire and grow. Since new entry is dampened, this negatively affects employment. As the likelihood of exit by businesses is greater, this also negatively affects employment. Periods of greater uncertainty, therefore, are likely to lead to lower employment.

The literature points to not all businesses being equally affected by credit market conditions. In different strands of this literature, the papers by Evans and Jovanovic (1989) and Fazzari, Hubbard and Petersen (1988), for example, offer insights on small versus larger firm effects. Gertler and Gilchrist (1994) strongly emphasize the negative impact of information asymmetric and credit constraints on smaller firms. Li (2008) shows the differential effects of market uncertainty and competition, project-specific uncertainty on venture capital investment.

Tying the two literatures on uncertainty and the effects of financing constraints on small businesses, the prediction that emerges from is that periods of greater uncertainty, via the credit market channel discussed above, is likely to have a dampening effect on employment and the number of businesses. Given that the effects of financing constraints are more likely to be borne by the smaller businesses, the prediction is that the negative effect of uncertainty will primarily manifest itself in data on small businesses. 
Finally, in contrast to the agency-based models noted above, Campbell and Cochrane (1999) demonstrate countercyclical variation of volatility and risk-premia, with more macroeconomic uncertainty after a crash. This yields a negative correlation between uncertainty and firms' key decision variables such as investment. Credit rationing that results from this effect can be alleviated by the existence of collateral assets. In general, and as noted by Gertler and Gilchrist (1994) and Fazzari et al. (1988), smaller business are far less likely to be in a position to offer meaningful collateral. On average, larger businesses which also tend to be older and more established, are in a position to offer significant collateral. This implies that the effect identified by Cochrane and Campbell will, on average, manifest itself more for smaller businesses.

From the asymmetric-information driven financing-constraints channel, we have the following hypotheses:

Hypothesis 1: Greater uncertainty is expected to negatively affect employment and number of businesses, and this effect is likely to be more pronounced for smaller businesses.

\subsection{Uncertainty and real-options}

A second channel that affects firms' decisions under uncertainty is real-options. Dixit (1989) shows that uncertainty and sunk costs imply an option-value of waiting and this raises the entry trigger price and lowers the exit trigger price. ${ }^{4}$ For prices below the entry trigger, the potential entrant holds on to its option to enter, and an incumbent firm does not exit at prices above the exit trigger. The intuition is that to enter during periods of greater uncertainty, firms require a premium over the conventional Marshallian entry price. And incumbent firms would wait longer to exit (i.e., let prices fall below average variable cost before they exit) as they know that to re-enter the market they would have to re-incur various transactions and sunk entry costs.

The key results related to entry and exit can be summarized as follows: (1) numerical results in Dixit (p.632-33) show that even small amounts of uncertainty are sufficient to generate significant changes in entry and exit patterns; and (2) the numerical simulations in Dixit (1989,

\footnotetext{
${ }^{4}$ Dixit and Pindyck (1994) outline the theoretical framework for studying firms' decision-making regarding entry and exit under uncertainty and sunk entry costs. Hopenhayn (1992) and Pakes and Ericsson (1998), for example, study firm dynamics with firm-specific uncertainty. These models, however, are best subjected to empirical tests using very micro-datasets as in Pakes and Ericsson, and is beyond the scope of our paper.
} 
p.632-33) and Dixit and Pindyck (Ch. 7, p.224-228; and Ch. 8.) show that an increase in uncertainty results in the entry trigger price increasing by more than the decrease in the exit trigger. These results reveal that entry is affected more than exit leading to negative net entry. In other words, periods of greater uncertainty lead to a decrease in entry but exits, while lower, continue at a closer to normal pace resulting in the industry experiencing a decrease in the number of firms.

The results are similar if we examine physical capital investment or employment. Dixit and Pindyck (1994) present an extensive analysis of the detrimental effects of uncertainty on investment. The effects on employment are qualitatively similar. If greater uncertainty retards entry and investment, it will also be expected to have a negative effect on employment.

From the real-options channel, we have the following hypotheses:

Hypotheses 2: Greater uncertainty is expected to negatively affect employment and number of businesses.

Unlike the financing-constraints channel which a priori is dominantly expected to affect smaller firms, the real-options theory does not allow a clear distinction of potential divergence in effects between smaller and larger firms. The inherent tendency to delay investments, employment, entry, among other strategic decisions, apply to firms of all classes.

\section{Empirical findings on the impact of uncertainty}

The empirical literature examining the effects of uncertainty is quite extensive and it is difficult to review the full spectrum of this literature. To offer a perspective in a convenient format, we present a table in Appendix A which summarizes selected papers. These are not meant to be comprehensive, but display the range of variables used to measure uncertainty (GDP, inflation, prices, energy prices, stock prices, among others), the specific statistical constructs to capture uncertainty (unconditional variance, conditional variance derived from regression estimates, survey measures), the level of aggregation of the studies (firm or industry level, and economy-wide), and the estimated quantitative and qualitative effects.

Regarding differences in the effects of uncertainty on small and large business, we briefly note some of the findings in the empirical literature useful for our analysis. Using industry-level data, Ghosal and Loungani (2000) find that the investment-uncertainty relationship is negative, and this negative impact is greater in industries dominated by small firms. Ghosal (1991) finds 
that uncertainty affects firms' choices of the capital-labor ratio, and that larger firms' input choices appear less affected by uncertainty. Results in Koetse and Vlist (2006) reveal that there are differential effects of uncertainty on input and output variables. Bianco, Bontempi, Golinelli and Parigi (2012) find small family firms' investments are significantly more sensitive to uncertainty than non-family firms. Findings in Ghosal and Loungani (1996) reveal that the effects of uncertainty on investment depends on whether the industry is relatively atomistic/competitive in structure. Lensink et al. (2005) find that uncertainty adversely affects firms' capital investment decisions, and discuss results related to firm size.

Regarding small entrepreneurial businesses, Li (2008) finds that market uncertainty encourages venture capital firms to delay investing, whereas competition and agency concerns prompt venture capital firms to invest sooner. Using data on venture capital investments in the U.S., Li and Mahoney (2011) find that venture capitalists tend to defer new investment projects in target industries with substantial market volatility. The negative impact is dampened if the target industry has high sales growth or if competition among venture capitalists is intense in the target industry. Their examination of the effects of uncertainty on venture capital funding is particularly important as smaller entrepreneurial businesses are often highly credit constrained from traditional sources, and have to rely on own cash-flows or venture funding (Baldwin, Gellatly and Gaudreault, 2002).

\section{Data description}

For our empirical analysis, we use data from multiple sources. Below we provide details of the datasets we use.

First, is the U.S. Small Business Administration (SBA) database. This database contains information on various economic and business variables by 'size of businesses' generally over the period 1988 to 2011. Data by business size classification were not available prior to 1988. From the SBA database we use annual data on employment by the size of business. The SBA database also provides information on the number of firms according to the size of firms. It is important to note that the SBA data are 'aggregated' in the sense that they provide data on, say, the total number of small businesses in the entire U.S. economy. In other words, the data are not firm-or-industry specific. As an illustration, if there are a total of 100 businesses in the U.S. in a given year, the SBA database tells us how many of these were large, medium of small, by 
specific firm-size classes. While the SBA data are not helpful in examining firm-or-industryspecific issues, they are very useful in gauging an economy-wide picture. In our context, the SBA data allow us to examine how uncertainty may affect employment and the total number of businesses by different firm-size classes.

Second, are some U.S. macroeconomic data we use in our analysis. Data on real GDP and GDP implicit price deflator are from the Federal Reserve Economic Data. The data on S\&P 500 stock price index are from Yahoo Finance. And data on fuel price index are from the U.S. Bureau of Labor Statistics (BLS); the fuel price index contains information on a broad range of the most commonly used fuels by producers, such as gasoline, electricity, natural gas, heating oil, among others.

Next we create firm size classes to examine the potential smaller versus larger business effects. We use the following size classifications:

1. 'All' businesses;

2. 'Large' businesses - these are businesses with $\geq 500$ employees;

3. 'Small' businesses - these are businesses with <500 employees; and

4. 'Smaller' businesses - these are businesses with $<20$ employees.

The 500 employee cutoff is the one used by the U.S. SBA, and we use this as the baseline. We consider an additional cutoff of <20 employees for the following reasons: (a) a 500 employee firm is relatively large, so we wanted to consider an alternate cutoff for defining small; (b) data with the <20 employee cutoff was available consistently for both our variables (employment and number of businesses); and (c) a large percentage of the truly small business fall in this category.

In our estimation of growth employment and number of businesses specifications, we will present estimates for each of the four groupings (1-4) noted above. In Figures 1 and 2 we display the time paths for the growth of employment and number of businesses by size class. Table 1 presents the summary statistics for the growth of employment and number of businesses by size class.

\section{Measures of uncertainty}

As noted in section 3, Appendix A summarizes selected papers and displays the range of variables used to measure uncertainty (GDP, inflation, prices, energy prices, stock prices, survey opinions, among others), and the specific statistical constructs to capture uncertainty 
(unconditional variance, conditional variance derived from regression estimates, survey forecast variance). The broader literature reveals a wide range of variables and methods to capture uncertainty. In the spirit of this literature, we construct six measures to examine the impact of uncertainty.

As noted in section 4, our data are U.S.-wide and include all relatively smaller and larger businesses in the U.S. Since the data are designed to portray a broader economy-wide picture, our uncertainty measures are created using economy-wide indicators.

First, we use the forecasts from the Survey of Professional Forecasters (henceforth, SPF) provided by the Federal Reserve Bank of Philadelphia. The SPF asks professional forecasters to give their forecast for 32 key macroeconomic variables, including GDP, industrial production, inflation, and unemployment, among other variables. The forecasters provide quarterly and annual forecasts for the current year and the following year. The respondents are asked to attach a probability to each of a number of pre-assigned intervals over which their forecast may fall. The Philadelphia Fed then takes the mean probabilities over the individual respondents and reports them in the SPF release in the form of a histogram. From the survey we use forecasts for growth of GDP and industrial production to construct two measures of uncertainty. We use GDP growth as it is the broadest measure of economic activity. We use growth of industrial production as the other measure as it is the most cyclical component of the economy, and is used by many forecasters as a leading indicator. Our measures of uncertainty are constructed as the within-year variance of survey forecasts for growth of GDP and industrial production. These two measures of uncertainty are labeled $\sigma_{s p f g d p, t}^{2}$ and $\sigma_{s p f i n d, t}^{2}$, with $s p f$ denoting 'survey of professional forecasters'. 5

Second, we use forecasting specifications to construct four additional measures related to uncertainty about:

1. real GDP growth. This indicates the overall state of the economy capturing demand and supply effects; ${ }^{6}$

\footnotetext{
${ }^{5}$ In a complementary literature, some differentiate between uncertainty versus disagreement. Compare two contexts: experts agree that there is a lot of uncertainty on the future growth rate; experts are confident about their estimation of future growth, but these estimations are very heterogeneous. Gollier and Zeckhauser (2005) demonstrate the effect of disagreement on the aggregate risk premium. While distinguishing between the effects of uncertainty v. disagreement on firms' decision variables is a useful exercise, we do not explore the implications of this in the current paper.

${ }^{6}$ GDP uncertainty measures, in different forms, have been used by, for example, Driver et al. (2005), Asteriou et al. (2005) and Bloom (2009).
} 
2. inflation rate. We measure inflation as the annual percentage growth of the GDP deflator. Inflation uncertainty captures effects related to input and product prices, as well as affecting firms' real borrowing rates; ${ }^{7}$

3. stock prices. We use the S\&P500 stock price index. As with real GDP, this is an indicator of the overall state of the economy, and forward looking indicator of investor and business confidence; ${ }^{8}$ and

4. real fuel price growth. Here we use the Bureau of Labor Statistics price index of a range of commonly used fuels by businesses. The nominal fuel price index is converted to real values after deflating by the implicit GDP deflator. This variable serves to proxy a critical input - fuels and energy - price for businesses. ${ }^{9}$

To create our measures of uncertainty, we use the following procedure. We assume that firms use a forecasting equation to predict future values of the relevant variable, an economywide indicator in our case. As noted earlier, since our data on businesses are U.S.-wide, our uncertainty measures are also created using economy-wide variables related to GDP, inflation, stock prices, and fuel prices.

As our baseline, we use a second-order autoregressive, $\operatorname{AR}(2)$, specification as the forecasting model. AR(n) models are based on Box and Jenkins (1970) formulation for forecasting economic variables, and historically they have performed well in forecasting exercises (e.g., Meese and Geweke, 1984; Marcellino, Stock and Watson, 2003). Given this literature, and our annual time-series data for the smaller and larger business variables, we use this methodology to forecast the relevant state variables.

The forecasting specification is:

(1) $Z_{t}=\alpha_{0}+\alpha_{1} Z_{t-1}+\alpha_{2} Z_{t-2}+\varepsilon_{t}$,

\footnotetext{
${ }^{7}$ Inflation has been used to construct uncertainty measures by, for example, Huizinga (1993), Fountas et al. (2006) and Elder (2004).

${ }^{8}$ Stock prices have been used to measure uncertainty by, for example, Bloom (2009), Chen et al. (2011), Bloom et al. (2007), Greasley et al. (2006), and Stein et al. (2010).

${ }^{9}$ Fuel and energy prices have been used to construct uncertainty measures by, for example, Koetse et al. (2006), Kilian (2008) and Guo et al. (2005).
} 
where Z is either: (i) real GDP growth; or (ii) inflation rate; or (iii) S\&P500 growth; or (iv) real fuel price growth. From specification (1), the predicted values represent the forecastable component. The residuals:

(2) $\hat{\varepsilon}_{t}=Z_{t}-\left(\hat{\alpha}_{0}+\hat{\alpha}_{1} Z_{t-1}+\hat{\alpha}_{2} Z_{t-2}\right)$,

represent the unsystematic, or unforecastable, component. Since $\hat{\varepsilon}_{t}$ can take positive or negative values, we use the squared value of $\hat{\varepsilon}_{t}$, interpreted as the conditional-variance, as our measure of uncertainty about the relevant variable. Using the residuals from forecasting equations and conditional-variance to construct uncertainty measures is common: see, for example, the insightful review in Lensink, Bo and Sterken (2001), and the references cited in the preceding footnotes. If the forecasting specification is for GDP (i.e., Z is real GDP growth), then we denote the uncertainty measure as:

(3) $\sigma_{g d p, t}^{2}=\left(\hat{\varepsilon}_{g d p, t}\right)^{2}$.

Using this procedure for our four economy-wide variables $(Z)$, we obtain four measures of uncertainty denoted by: (i) $\sigma_{g d p, t}^{2}$; (ii) $\sigma_{\text {infl,t }}^{2}$; (iii) $\sigma_{s p 500, t}^{2}$; and (iv) $\sigma_{f u e l, t}^{2}$. While we report our baseline results using an $\mathrm{AR}(2)$ specification for (1), as we note in section 7, our results are robust to including longer lag lengths and alternative specifications.

To estimate the forecasting specification (1), we use available data on Z from 1960 to 2011. The rationale is as follows. The objective is obtain a good forecasting specification, which is better done with a longer time-series ensuring that the parameters of the equation are estimated precisely. While data on GDP, inflation and S\&P 500 are available for earlier periods, the BLS fuel price indices are available starting 1960. So we use 1960 as the starting year for which all of our variables (that we consider for $\mathrm{Z}$ ) are available. The terminal period, 2011, is the same as the last period for which the small business data are available. This implies that the generated timeseries in our four uncertainty measures $\sigma_{g d p, t}^{2}, \sigma_{\text {infl,t }}^{2}, \sigma_{s p 500, t}^{2}$ and $\sigma_{f u e l, t}^{2}$ are over 1962-2011 (two initial observations are lost due to use of lagged values in specification 1).

While our AR(.) forecasting equation is fairly standard, the length and frequency (annual from 1988-2011) of the available SBA business variables restricts us from considering alternate 
procedures, such as using ARCH or GARCH models, to construct measures of uncertainty. While this may be viewed as a limitation, the SBA data on employment and number of businesses are simply not available at a higher frequency. Since we need to harmonize the estimation periods and frequency, we are restricted to using annual data to forecast our specification (1).

A final comment is that we are using two broad sets of uncertainty measures: from survey of professional forecasters, and using regression-based forecasting specifications. While the regression-based measure admittedly has various econometric issues we need to grapple with, the survey of professional forecasters measure is not being generated by a regression-based procedure. In this sense, it acts a very important check of robustness to our estimates and inferences.

\section{Empirical Specification}

There is a substantial literature on estimation of dynamic specifications related to firms' decision variables, such as new investments in physical capital, employment, capital investments for entry into markets, among others. Holt et al. (1960), Kennan (1979), Hendry et al. (1983) and Jorgenson (1986) present detailed expositions of the underlying theory behind the econometric models. Following this literature, we use a partial-adjustment framework to structure our empirical specification. The partial-adjustment model is based on a quadratic cost-minimizing framework where firms, when making their optimal adjustment decisions (e.g., related to investment or employment), aim to minimize disequilibrium and adjustment costs.

The disequilibrium costs arise due to lost revenue (and profits) from having the decision variables at sub-optimal levels. For example, delayed entry investment, delayed employment adjustments, delayed expansion of existing facilities, among others, can lead to lost revenues and profits. The adjustment costs are incurred when the firm attempts to align the actual values of the decision variables to their optimal levels. A firm's attempt to rapidly align the decision variable to its optimal level - incur capital investments to enter a market or expand employment too 
rapidly - will result in higher adjustment costs. Disequilibrium costs motivate firms to adjust the decision variable faster, whereas adjustment costs induces the firm to align it to optimal levels in a smoother, slower, adjustment process. The actual adjustment speed of the decision variable will be a weighted-average of these two opposing effects.

Let $\mathrm{X}$ be a decision variable for the firm (e.g., capital investment to enter a market, employment, expand existing facilities). The partial adjustment model is given by: ${ }^{10}$

(4) $X_{i, t}-X_{i, t-1}=\lambda\left(X_{i, t}^{*}-X_{i, t-1}\right)$

where $i$ and $t$ denote firm and time, $X^{*}$ the optimal value of $X$, and $\lambda$ the speed-of-response parameter. In (4), actual adjustment $\left(X_{i, t}-X_{i, t-1}\right)$ is a fraction $\lambda$ of the 'desired' intertemporal adjustment $\left(X_{i, t}^{*}-X_{i, t-1}\right)$. High (low) values of $\lambda$ imply high (low) speed-of-response. Since $\mathrm{X}^{*}$ is private information for the firm and not observed directly by the external researcher, it is modeled as a function of relevant driving variables.

In our case, $\mathrm{X}$ can be, for example, employment. We model employment as a function of its own intertemporal dynamics (captured by lagged values), expectations of macroeconomic conditions (expected GDP growth), and uncertainty. The optimal choice of $\mathrm{X}^{*}$ is therefore a function of future expectations of GDP growth, $G D P_{t}^{e}$; the intuition being that if expected economic conditions are improving, firms will plan to adjust their decision variable, $\mathrm{X}$, upwards. If GDP follows an autoregressive process of order $\mathrm{n}, \mathrm{AR}(\mathrm{n})$, then $G D P_{t}^{e}$ can be replaced by its forecasting equation consisting of lagged values of GDP: $G D P_{t}^{e}=\sum_{k} \gamma_{k} G D P_{t-k}$, where $\mathrm{k}=0,1,2, \ldots, \mathrm{n}$.

\footnotetext{
${ }^{10}$ As the theoretical solution for these models are well established (e.g., Holt et al. 1960; Kennan, 1979), we do not repeat the entire model structure here.
} 
As discussed earlier, we use uncertainty as the other variable affecting firms' decisions to adjust $\mathrm{X}$. With these considerations, we model $X_{t}^{*}=f\left(G D P_{t}^{e}, \sigma_{[.], t}^{2}\right)$, where $\sigma_{[.], t}^{2}$ is a measure of uncertainty (section 5). Using the expression for $G D P_{t}^{e}$ from above, we get:

(5) $X_{i, t}^{*}=\sum_{k} \gamma_{k} G D P_{t-k}+\sum_{m} \xi_{m} \sigma_{[.] t-m}^{2}$,

where $\mathrm{k}$ and $\mathrm{m}$ are the appropriate lag lengths.

With the above structure, the partial-adjustment model for estimation is given by (6):

(6) $\dot{M}_{t}=\alpha_{0}+\beta(L) \sigma_{[-], t}^{2}+\gamma(L) G \dot{D} P_{t}+\delta(L) \dot{M}_{t}+v_{t}$,

where $M_{t}$ (replacing X) is a measure of business activity (in our case, growth of employment or growth of number of businesses), L represents the lagged operator, $G D P_{t}$ is real GDP growth, $\sigma_{[-], t}^{2}$ is the measure of uncertainty measured in natural logarithms, ${ }^{11}$ and $v_{t}$ is the error term. As described earlier, the six alternative measures of uncertainty we use are $\sigma_{s p f g d p, t}^{2}, \sigma_{s p f i n d, t}^{2}$, $\sigma_{g d p, t}^{2}, \sigma_{i n f l, t}^{2}, \sigma_{s p 500, t}^{2}$ and $\sigma_{f u e l, t}^{2}$.

Since we are interested in the short-term effects of uncertainty on business activity, and that the underlying data on employment and the number of businesses contain trends, we measure $M_{t}$ in logarithmic first-differences; that is, rate of growth (annual percentage change) and denoted by $\dot{M}_{t}$.

Our experiments with lag lengths indicated: (1) for the majority of specifications only one autoregressive lag of $\mathrm{M}$ was significant, but in a few specifications two lags were significant;

\footnotetext{
${ }^{11}$ We enter the uncertainty measure in natural logarithms as the mean values of the uncertainty variables vary enormously in size across the different measures (see table 1). Using the actual values of the uncertainty variables in the estimated regressions resulted in large numerical differences in the estimates due to pure scaling effects. Entering the uncertainty variables in natural logarithms resulted in no differences in inferences (related to the small versus large business differences) compared to entering them in levels. Estimates with the uncertainty variables entered in levels (not logarithms) are available on request.
} 
(2) GDP effects were captured by current and one lag; (3) at most one lag of the uncertainty variable was significant.

As noted in section 4, the available data on Small Businesses are annual and cover the period 1988-2011. We, therefore, estimate specification (6) over 1988-2011. ${ }^{12}$ Estimating (6) informs us about the impact of uncertainty on growth of employment or growth of number of businesses, after controlling for overall economic activity (GDP growth) and the dynamic intertemporal lagged structure for the included variables. ${ }^{13}$

In our examination of the effects of uncertainty on growth of employment and number of businesses, we present estimates for four groups noted in the data section 4: (1) All businesses; (2) Large businesses ( $\geq 500$ employees); (3) Small businesses (businesses with $<500$ employees); and (4) Smaller businesses (<20 employees).

\section{Estimation results}

Our results are presented as follows. First, in tables 2-3, we present the estimates from specification (6), and highlight key observations. These tables inform us of the statistical significance of the effects and the qualitative inferences. Second, due to considerable differences in the mean values of variables in the estimated regressions, is difficult to assess the quantitative magnitudes of the effects of uncertainty. To do this, in tables 4-5 we present the quantitative effects; these are calculated as the effect of a one-standard-deviation increase in uncertainty on growth of employment or growth of the number of businesses. Third, to present the quantitative effects calculations in a more compact form, in tables 6-7 we present the total quantitative effects. These numbers are systematized and aggregated from those in tables 4-5, and present a clear picture of the quantitative effects of uncertainty, and the relative effects of uncertainty versus GDP growth.

\subsection{Estimates}

Uncertainty and growth of employment

\footnotetext{
12 As noted earlier, our six uncertainty measures are constructed over a longer time period, we use their values over 1988-2011 in estimating specification (6).

${ }^{13}$ As we note in section 7.3, our experiments using longer lag lengths did not provide additional insights into the effects of uncertainty.
} 
The results for the growth of employment specifications are presented in tables 2.1 and 2.2. Table 2.1 presents estimates for All and Large businesses, and table 2.2 presents estimates for the Small and Smaller size classes.

In table 2.1 , the $\bar{R}^{2}$ 's are in the $75 \%$ to $87 \%$ range indicating good fit of the specification. The estimates of the first-order autocorrelation coefficient, $\rho$, are relatively low on average. The estimates show that uncertainty related to GDP, Inflation, S\&P500 and Fuel prices have a negative effect on the growth of employment for All businesses, but the timing (contemporaneous versus lagged) and size of the estimated coefficients vary. Turning to the Large businesses, only Inflation and Fuel price uncertainty dampen growth of employment, and the estimated coefficients are a bit smaller for the Large business group.

For the small business groups in table 2.2 , the $\bar{R}^{2}$ 's are in the $62 \%$ to $78 \%$ range. The estimates of the first-order autocorrelation coefficient, $\rho$, are generally quite low. The estimates show that aside from the mixed inferences from the Inflation and S\&P500 based measures, uncertainty related to the two survey-based measures, and GDP, Inflation and Fuel prices have a negative effect on growth of employment for the Small and Smaller businesses.

The broad inferences from the estimates in tables 2.1 and 2.2 are as follows. Most of the uncertainty coefficients for Large businesses are not significant, which imply that employment growth in Large businesses are not sensitive to uncertainty. The results show only GDP uncertainty and stock price uncertainty have negative and significant effects on large firms. In contrast, almost all the uncertainty coefficients are significant for the Small and Smaller business groups. The results show that small businesses' employment decisions are more likely to be adversely affected by uncertainty than those of large businesses.

\section{Uncertainty and growth of number of businesses}

The results for the growth of the number of businesses specifications are presented in tables 3.1 and 3.2. Table 3.1 presents estimates for All and Large businesses, and table 3.2 presents estimates for the Small and Smaller size classes.

In table 3.1, the $\bar{R}^{2}$ 's for All businesses specifications are in the $70 \%$ to $75 \%$ range, while they are only in the $40 \%$ to $55 \%$ range for the Large businesses, indicating lower explanatory power for the latter group. Aside from a couple of specifications, the estimates of the first-order 
autocorrelation coefficient, $\rho$, are relatively low. The estimates show that uncertainty related to the survey-based measures, and GDP and S\&P500 have a negative effect on the number of All business, but the quantitative effects vary. Fuel price or inflation uncertainty does not appear to affect the growth of the number of All businesses. Turning to Large businesses, we see that four of the uncertainty measures appears to decrease the growth of the number of these businesses.

For the small businesses specifications in table 3.2, the $\bar{R}^{2}$ 's are in the $50 \%$ to $60 \%$ range for the Smaller group, and in the 70\% range for the Small group. The estimates of the first-order autocorrelation coefficient, $\rho$, are uniformly low. The estimates show that uncertainty related to both the survey-based measures, and GDP growth and Inflation have a negative effect on the number of Smaller business, but fuel price and S\&P500 uncertainty does not appear to affect this group. Turning to the Small group, the two survey-based measures, and GDP and Inflation uncertainty have a negative effect on the growth of the number of businesses.

Based on the estimates in tables 3.1 and 3.2, uncertainty has a negative impact on the growth of the number of businesses, and, as compared to the growth of employment specifications, this effect appears to be more mixed across the size classes. Although for Large businesses group, GDP uncertainty, stock price uncertainty and fuel price uncertainty have significant negative effect on number of businesses, other uncertainty measures do not yield statistically significant results. On the other hand, almost all uncertainty measures show significant negative effect on the number of businesses for Small and Smaller businesses. Thus, entry and exit decisions of smaller businesses are more sensitive to uncertainty.

\section{Broad inferences from estimates}

The overall inferences we draw from the estimates presented in tables 2 and 3 are that uncertainty dampens growth of employment, and the effects appear to be concentrated in the Smaller (<20 employees) and Small (<500 employees) groups. At broad brush, our findings appear supportive of the results from the theoretical models we discussed in section 2 . The effects on the number of businesses appears to be more mixed and need further investigation. The fact that we find the effects related to uncertainty even after controlling for GDP growth and the lagged dynamics, makes our finding even more noteworthy. 
The estimated specifications include real GDP growth, and model the dynamics of the included variables via lagged effects. Real GDP growth is a key control variable in either growth of employment or growth of number of businesses specifications. With increasing GDP growth, business opportunities are expected to expand allowing for growth of jobs as well as new businesses. As expected, the regression estimates in tables 2-3 indicate that GDP growth, as contemporaneous and/or lagged effect, is important in all specifications.

Table 2 shows that GDP growth has a significant and positive effect on the growth of employment regardless of the firms' size. When we compare the effect on large and small businesses, we see that GDP has a larger positive effect on large firms in a $51 \%$ to $74 \%$ range. For the smaller firms group ( $<20$ employment), the effect range varies from $6 \%$ to $47 \%$. Table 3 shows that the GDP growth has a complex effect on number of businesses. In all groups, we see some positive, negative and not significant coefficients. Also, the magnitudes of the effects are mixed. GDP growth appears to affect the large businesses the most. For the Small $(<500$ employment) and Small (<20 employment), we see that the first lag of GDP growth affects the growth number of businesses positively while the second lag affects it negatively.

\subsection{Assessing quantitative effects}

Since the means and standard deviations of the dependent and explanatory variables vary widely (table 1), the coefficient estimates in tables 2 and 3 do not convey a clear sense of the 'quantitative' importance of the effects related to uncertainty and GDP growth. Tables 4.1 and 4.2 present the quantitative effects for growth of employment, and tables 5.1 and 5.2 for growth of number of businesses. In tables 4.1 and 4.2 we do not report the regression statistics and details about lagged coefficients and focus only on uncertainty and GDP growth effects.

The numbers in tables 4 and 5 show the effect of a one-standard-deviation (henceforth, one-s.d.) increase in the relevant independent variable. That is, if a particular uncertainty measure increased by one-s.d., the reported numbers show the estimated increase in growth of employment or growth of number of businesses. We do not report the standard errors in tables 45 as they are the same as in tables 2 and 3. We keep the asterisk * notation to denote that the particular quantitative effects are statistically significant at least at the $10 \%$ level. Finally, in the headers for tables 4-5, we note the mean values of growth of employment and growth of number of businesses for the relevant samples. 
As an illustration to interpret the numbers, consider table 4.2 and the reported numbers for the Smaller (<20) group. The reported numbers for $\sigma_{\text {spfgdp }}^{2}$ (column S1) are -0.0039 and 0.0044. Since both are statistically significant, the total effect is the sum of the two: -0.0083 . This implies that a one-s.d. increase in $\sigma_{\text {spfgdp }}^{2}$ results in the growth of employment decreasing by 0.0083. This decline is to be compared to the mean growth of employment of 0.0053 for the Smaller $(<20)$ size group. The uncertainty-generated decline, therefore, represents a relatively large quantitative effect for this group and specific measure of uncertainty.

To facilitate easy interpretation of the numbers, we summarize all of the effects in table 4-5 in tables 6-7. In our above illustration, the total effect was -0.0083. This number appears in table 6, column 1 and row 4; that is, for uncertainty measure $\sigma_{\text {spfgdp }}^{2}$ and size group Smaller $(<20)$.

The numbers in tables 6-7 and therefore interpreted as the total quantitative effects. In displaying the numbers in tables 6-7, we only report those effects that are statistically significant. Since we are considering significance at least at the $10 \%$ level, this is a fairly safe-harbor threshold. If an estimate was not significant at least at the $10 \%$ level, for our illustrative purposes we assign a value of 0.0 .

In viewing the numbers in tables 6-7, the final detail is that the column labeled $\overline{\sigma^{2}}$ which represents the mean value of all the numbers in that particular row. This is then interpreted as the 'average estimated quantitative effect' of uncertainty (across the various measures) on growth of employment or growth of the number of businesses for that particular sample (by size class). The column labeled $\overline{G D P}$ is interpreted similarly; the average estimated quantitative effect of GDP growth on growth of employment or growth of the number of businesses for that particular sample (by size class).

With these details, we are now in a position to comment on the total estimated quantitative effects for uncertainty and GDP growth.

From table 6, we see that the difference in effects between the Large and Small size groups is dramatic, with the Small group effect being about 4.5 times larger. While there are some variations across the specific measures of uncertainty, the effects of uncertainty on growth of employment, for all practical purposes, are felt largely by the relatively smaller businesses. The total quantitative effect for the Smaller (<20) group is somewhat smaller than the Small $(<500)$ size group. This implies that the effects of uncertainty on some of the intermediate size 
classes is likely to be large. In table 6, comparing the uncertainty effects to the GDP growth effects, we find that the quantitative effects of GDP growth are consistently larger.

Turning to the growth of number of businesses in table 7, the quantitative effects on the Large businesses are mixed (as was noted in table 3.1); the average effect as noted in column $\overline{\sigma^{2}}$ is positive. Aside from some variation across the uncertainty measures, the impact on growth of the number of small businesses is negative. The quantitative effects, therefore, show that smaller businesses are adversely impacted. As was the case with the growth of employment effects in table 6, the effect of GDP growth on the number of businesses is consistently larger than those for uncertainty.

\subsection{Comments on robustness}

Our analysis builds in several checks of robustness. First, the uncertainty measures are constructed using two broad approaches: survey of professional forecasters based; and forecasting regression generated. Further, we consider uncertainty about several alternative variables: GDP, industrial production, S\&P500, inflation and fuel prices. In combination, these offer a measure of reassurance that our results are not being driven by a single measure, procedure or variable.

In addition to the above, we conducted the following checks of robustness. First, we estimated our forecasting specification (1) using longer autoregressive lag lengths, and generating the uncertainty measures. Second, we used augmented forecasting specifications where apart from using autoregressive lags of $Z$ - as in specification (1) - we also included the growth of oil prices and a monetary policy variable, the Federal Funds Rate. The impact of oil

prices and monetary policy actions on economic variables such as GDP growth, inflation, among others have been extensively examined, and are standard in the macroeconomic literature. These controls are important because if agents and firms are using these driving variables to forecast movements in key economy-wide variables, ignoring them would produce potentially biased estimates of our uncertainty measures.

Across these range of experiments, our broader set of results and inferences related to the impact of uncertainty on growth of employment and growth of the number of businesses remain intact. Due to the rather space-consuming nature of the tables (as is evident from the set of tables 2 and 3), we do not report these in the paper. 


\section{Discussion of results and implications}

Our paper provides the first set of evidence on the differential effects of uncertainty, by firm size, on employment growth, with complementary results related to the growth of the number of businesses. Our findings on the differential effects of uncertainty on the relatively smaller versus larger businesses is quite robust across alternative procedures to construct the measures of uncertainty (information from the survey of professional forecasters versus forecasting regression based methods), and alternative variables to measure uncertainty about (GDP, industrial production, inflation, S\&P500 and fuel prices). These results appear even after controlling for GDP growth, and controls for lagged dynamics of the included variables.

As we noted in the introduction, the literature notes a rough equivalence between small businesses and entrepreneurship. Given the significance of entrepreneurship in generating new businesses, technologies and employment, our results on the effects of uncertainty on small businesses, therefore, also sheds light on the potentially adverse effects on entrepreneurial ventures.

The spirit of our results are not in isolation as earlier studies on uncertainty, related to investment spending and using very different datasets and estimation procedures, have found similar results related to firm size: for example, Bianco, Bontempi, Golinelli and Parigi (2012), Ghosal and Loungani (1996 and 2000), Ghosal (1991), Koetse and Vlist (2006) and Lensink et al. (2005). This is reassuring as it points to our results not being an artifact of our specific dataset, methods of estimation, and construction of uncertainty variables.

We used the insights from the theories related to information-asymmetry generated financing-constraints, and real-options, to obtain predictions on the impact of uncertainty on employment and number of businesses. As we noted in section 2, the real-options theory does not offer direct predictions related to why small and large firms may differ in their responses to uncertainty. ${ }^{14}$ The asymmetric-information related financing-constraints theory on the other hand

\footnotetext{
${ }^{14}$ Studies on industry dynamics and firm-churning data show that most business churning occurs at the smaller firm end: for example, Audretsch (1995), Sutton (1997) and Caves (1998). To this extent, purely as an accounting matter, one can argue that if we observe effects, it will more likely be in the smaller business category. But this is not a direct theoretical prediction.
} 
offers clear predictions, with smaller firms being the ones most likely to be adversely affected by uncertainty due to their greater likelihood of being credit constrained. ${ }^{15}$

Given that the data we use from the U.S. Small Business Administration are relatively aggregated, it is difficult to clearly disentangle which of these two theories may be playing the more dominant role. It is fair to assume that both channels are important in determining the outcomes, with somewhat greater support for the financing-constraints channel due to the more direct predictions.

To the question as to why governments might pay special attention to small businesses, there are several responses. First, we noted earlier in the paper that a large fraction of employment and businesses fall into the smaller categories. Second, a number of emerging structural factors - such as those related to globalization and banking sector consolidation - are likely to favor large businesses relative to the smaller ones. These considerations alone provide important economic policy justification.

If it is true that our results on the effects of uncertainty in important part are being driven by the financing-constraints channel, then potential policy implications emerge, primarily in the form of initiatives and instruments designed to partly ease the financing-constraints faced by smaller businesses. As with many governments worldwide, the U.S. recently implemented policies and programs to help small businesses bridge the capital and market gap and encouraged public-private partnerships to support small business and entrepreneurship by, for example: (a) supporting more than $\$ 53$ billion in SBA loan guarantees to more than 113,000 small businesses; (b) awarding more than $\$ 221$ billion in Federal contracts to small businesses (FY 2009 through April 30, 2011); and (c) awarding more than $\$ 4.5$ billion in research funding through the Small Business Innovation and Research Program during FY 2009 and FY 2010. ${ }^{16}$

Such initiatives, along with appropriate lending policies, can help ease some of the financing-constraints faced by smaller businesses in times of economic and financial distress. ${ }^{17}$

\footnotetext{
${ }^{15}$ The literature has noted important differences between smaller and larger businesses, and point to smaller firms being relatively credit-constrained. E.g., Audretsch and Elston (1997), Fazzari, Hubbard and Petersen (1988), Gertler and Gilchrist (1994), Evans and Jovanovic (1989), Lensink, Bo and Sterken (2001), Ghosal and Loungani (2000), Himmelberg and Petersen (1994) and Winker (1999).

${ }^{16}$ The National Economic Council (2011) and Sheets and Sockin (2012) provide extensive discussion on the importance of small businesses and policy.

17 The papers by Audretsch and Elston (1997, 2002), for example, provide important insights in this dimension from German policy initiatives.
} 
By doing so, and in the context of this paper, such policies may also help alleviate some of the negative impact of uncertainty on smaller businesses.

In ongoing research we are pursuing more detailed analysis using firm and industry level data to more precisely disentangle the likely effects of the information-asymmetry versus realoptions theories. This may also help us with better insights related to the economies exiting from the ongoing financial and economic crisis. 


\section{Appendix A: Selected empirical findings on the impact of uncertainty}

The papers included below are not meant to be a comprehensive review of the studies in this area, but to display the range of variables used to measure uncertainty (GDP, inflation, prices, energy prices, stock prices, among others), the specific statistical constructs to capture uncertainty (unconditional variance, conditional variance derived from regression estimates, survey measures), the level of aggregation of the studies (firm-level, industry level, economywide), and the estimated quantitative and qualitative effects.

\begin{tabular}{|c|c|c|c|}
\hline Paper & $\begin{array}{l}\text { Data } \\
\text { Estimation method }\end{array}$ & $\begin{array}{l}\text { State variables } \\
\text { Uncertainty measure }\end{array}$ & Estimation results \\
\hline $\begin{array}{l}\text { Lensink, Robert, Paul van Steen and } \\
\text { Elmer Sterken. "Uncertainty and } \\
\text { Growth of the Firm," Small Business } \\
\text { Economics, 2005, 381-391. }\end{array}$ & $\begin{array}{l}\text { Survey of 1,097 Dutch firms in } \\
1999 . \\
\text { Logit model. }\end{array}$ & $\begin{array}{l}\text { Sales. Return on } \\
\text { Investment. } \\
\text { Conditional } \\
\text { variance/mean. }\end{array}$ & $\begin{array}{l}\text { Uncertainty has a negative impact on } \\
\text { the size of investment, no matter what } \\
\text { the type of investment is used. Smaller } \\
\text { firms have a lower probability to invest } \\
\text { if uncertainty increases. }\end{array}$ \\
\hline $\begin{array}{l}\text { Koetse, Mark J., Arno J. van der Vlist } \\
\text { and Henri L.F. de Groot. "The Impact } \\
\text { of Perceived Expectations and } \\
\text { Uncertainty on Firm Investment," } \\
\text { Small Business Economics, 2006, } \\
\text { 365-376. }\end{array}$ & $\begin{array}{l}\text { Survey of } 135 \text { plant locations in } \\
\text { Netherlands in } 1998 . \\
\text { Tobit model. }\end{array}$ & $\begin{array}{l}\text { Wages. Energy prices. } \\
\text { Output prices. } \\
\text { Survey based. }\end{array}$ & $\begin{array}{l}\text { Uncertainty has a larger influence on } \\
\text { decision making in small firms than in } \\
\text { large firms specifically for investment } \\
\text { in energy-saving technologies. }\end{array}$ \\
\hline $\begin{array}{l}\text { Bo, Hong, and Elmer Sterken. } \\
\text { "Volatility of the interest rate, debt } \\
\text { and firm investment: Dutch } \\
\text { evidence," Journal of Corporate } \\
\text { Finance, 2002, 179-193. }\end{array}$ & $\begin{array}{l}\text { Data for } 41 \text { Dutch listed firms } \\
\text { from } 1984 \text { to } 1995 . \\
\text { Panel Data, , Fixed effect } \\
\text { estimation. }\end{array}$ & $\begin{array}{l}\text { Interest rate. } \\
\text { Conditional variance. } \\
\text { ARCH model. }\end{array}$ & $\begin{array}{l}\text { Cross-effect of the interest rate } \\
\text { volatility and debt on investment is } \\
\text { positive. This effect is more important } \\
\text { for highly indebted firms than for less- } \\
\text { indebted firms. }\end{array}$ \\
\hline $\begin{array}{l}\text { Driver, Ciaran, and Brendan Whelan. } \\
\text { "The Effect of Business Risk on } \\
\text { Manufacturing Investment," Journal } \\
\text { of Economic Behavior and } \\
\text { Organization, 2001, 403-412. }\end{array}$ & $\begin{array}{l}\text { Disaggregated survey data of } \\
\text { Ireland in } 1995 . \\
\text { Comparing the percentage of } \\
\text { different respondents in the } \\
\text { survey questions. }\end{array}$ & $\begin{array}{l}\text { Future demand and } \\
\text { future price } \\
\text { Future unit input cost } \\
\text { Capacity } \\
\text { Delay risk } \\
\text { Subjective descriptions } \\
\end{array}$ & $\begin{array}{l}\text { No strong effect of risk due to } \\
\text { convexities. Risk did affect the timing } \\
\text { of investment for between a quarter and } \\
\text { a third of the sample. The greatest } \\
\text { caution in respect of timing was in the } \\
\text { Hi-tech sector which was also the sector } \\
\text { with the greatest damage from delay. }\end{array}$ \\
\hline $\begin{array}{l}\text { Oriani, Raffaele, and Maurizio } \\
\text { Sobrero. "Uncertainty and the Market } \\
\text { Valuation of R\&D within a Real } \\
\text { Options Logic," Strategic } \\
\text { Management Journal, 2008, 343-361. }\end{array}$ & $\begin{array}{l}\text { Data for } 290 \text { manufacturing } \\
\text { firms in UK from } 1989 \text { to } 1998 . \\
\text { Panel Data, Hedonic model }\end{array}$ & $\begin{array}{l}\text { Industry output. Patents. } \\
\text { Absolute percentage } \\
\text { difference. Inverse of } \\
\text { the median age. }\end{array}$ & $\begin{array}{l}\text { They find a U-shaped relationship } \\
\text { between market uncertainty and value } \\
\text { of investment. Also, they find an } \\
\text { inverted U-shaped relationship between } \\
\text { technological uncertainty and the value } \\
\text { of R\&D capital. }\end{array}$ \\
\hline $\begin{array}{l}\text { Bianco, Magda, Maria Elena } \\
\text { Bontempi, Roberto Golinelli and } \\
\text { Giuseppe Parigi. "Family Firms' } \\
\text { Investments, Uncertainty and } \\
\text { Opacity," Small Business Economics, } \\
\text { 2012, 1-24. }\end{array}$ & $\begin{array}{l}\text { Data for 2,959 Italian private } \\
\text { companies from } 1996 \text { to } 2007 . \\
\text { Panel data, GMM }\end{array}$ & $\begin{array}{l}\text { Sales. } \\
\text { Coefficient of variation. }\end{array}$ & $\begin{array}{l}\text { Family firms' investments are } \\
\text { significantly more sensitive to } \\
\text { uncertainty than nonfamily firms and } \\
\text { that is due to the greater opacity of } \\
\text { family firms and higher risk aversion, } \\
\text { rather than to the degree of sunk fixed } \\
\text { capital. }\end{array}$ \\
\hline $\begin{array}{l}\text { Bloom, Nick, Stephen Bond and John } \\
\text { Van Reenen. "Uncertainty and } \\
\text { Investment Dynamics," Review of } \\
\text { Economic Studies, 2007, 391-415. }\end{array}$ & $\begin{array}{l}\text { Data for } 672 \text { UK manufacturing } \\
\text { firms from } 1972 \text { to } 1991 . \\
\text { Panel data, GMM }\end{array}$ & $\begin{array}{l}\text { Stock returns. } \\
\text { Std. deviation of daily } \\
\text { stock returns. }\end{array}$ & $\begin{array}{l}\text { Effects of uncertainty are large. } \\
\text { Uncertainty distribution halves the first } \\
\text { year investment response to demand } \\
\text { shocks. }\end{array}$ \\
\hline $\begin{array}{l}\text { Ghosal, Vivek, and Prakash } \\
\text { Loungani. "Product Market } \\
\text { Competition and the Impact of Price } \\
\text { Uncertainty on Investment: Some } \\
\text { Evidence From US Manufacturing } \\
\text { Industries," Journal of Industrial } \\
\text { Economics, 1996, 217-228. }\end{array}$ & $\begin{array}{l}\text { Data for } 254 \text { US 4-digit SIC } \\
\text { manufacturing industries from } \\
1958 \text { to } 1989 . \\
\text { Panel data, fixed effect - IVE. }\end{array}$ & $\begin{array}{l}\text { Product price. } \\
\text { Rolling regression } \\
\text { based conditional std. } \\
\text { deviation. }\end{array}$ & $\begin{array}{l}\text { A negative relationship between } \\
\text { investment and price uncertainty only } \\
\text { exists in competitive industries. One } \\
\text { percentage increases in price } \\
\text { uncertainty is estimated to cause the } \\
\text { ratio of gross industry investment }(\mathrm{I} / \mathrm{K}) \\
\text { decrease by } 0.358 \text { for most competitive } \\
\text { industries. }\end{array}$ \\
\hline $\begin{array}{l}\text { Fuss, Catherine, and Philip } \\
\text { Vermeulen. "Firms' Investment } \\
\text { Decisions in Response to Demand } \\
\text { and Price Uncertainty," Applied } \\
\text { Economics, 2008, 2337-2351. }\end{array}$ & $\begin{array}{l}\text { Survey of } 279 \text { firms from } 1987- \\
2000 \text {, and another survey of } 319 \\
\text { firms from 1987-1999. } \\
\text { Panel data, GMM. }\end{array}$ & $\begin{array}{l}\text { Expectations of future } \\
\text { demand and prices. } \\
\text { Theil index. }\end{array}$ & $\begin{array}{l}\text { Demand uncertainty at the time of } \\
\text { planning depresses planned and realized } \\
\text { investment. One standard deviation } \\
\text { increases in demand uncertainty is } \\
\text { estimated to reduce } 6 \% \text { of the average } \\
\text { investment ratio. }\end{array}$ \\
\hline Ghosal, Vivek, and Prakash & Data for 330 US SIC 4-digit & Profits. & Investment-uncertainty relationship is \\
\hline
\end{tabular}




\begin{tabular}{|c|c|c|c|}
\hline $\begin{array}{l}\text { Loungani. "The Differential Impact of } \\
\text { Uncertainty on Investment in Small } \\
\text { and Large Businesses," Review of } \\
\text { Economics and Statistics, 2000, 338- } \\
\text { 343. }\end{array}$ & $\begin{array}{l}\text { manufacturing industries from } \\
1958 \text { to } 1991 . \\
\text { Panel data, IVE. }\end{array}$ & $\begin{array}{l}\text { Rolling regression } \\
\text { based conditional std. } \\
\text { deviation. }\end{array}$ & $\begin{array}{l}\text { negative and this negative impact is } \\
\text { greater in industries dominated by small } \\
\text { firms. }\end{array}$ \\
\hline $\begin{array}{l}\text { Huizinga, John. "Inflation } \\
\text { Uncertainty, Relative Price } \\
\text { Uncertainty, and Investment in U.S. } \\
\text { Manufacturing," Journal of Money, } \\
\text { Credit and Banking, 1993, 521-549. }\end{array}$ & $\begin{array}{l}\text { Data for } 450 \text { U.S. SIC } 4 \text {-digit } \\
\text { manufacturing industries from } \\
1954 \text { to } 1989 . \\
\text { Cross-sectional data. }\end{array}$ & $\begin{array}{l}\text { Real wage. Output } \\
\text { price. Real materials } \\
\text { price. } \\
\text { Conditional std. } \\
\text { deviation. } \\
\text { Bivariate ARCH model. }\end{array}$ & $\begin{array}{l}\text { Increased uncertainty about real wages } \\
\text { portends an immediate and large drop in } \\
\text { capital expenditures, while increased } \\
\text { uncertainty about real output price does } \\
\text { not. }\end{array}$ \\
\hline $\begin{array}{l}\text { Stein, Luke C.D., and Elizabeth C. } \\
\text { Stone. "The Effect of Uncertainty on } \\
\text { Investment: Evidence from Options," } \\
\text { Stanford University Working Paper, } \\
2010 .\end{array}$ & $\begin{array}{l}\text { Data for 2,230 US } \\
\text { manufacturing firms from } 1996 \\
\text { to } 2009 . \\
\text { Panel data, 2SLS. }\end{array}$ & $\begin{array}{l}\text { Stock price. } \\
\text { Expected volatility. }\end{array}$ & $\begin{array}{l}\text { They find a negative and statistically } \\
\text { significant relationship between } \\
\text { uncertainty and investment. The } \\
\text { coefficients are larger after addressing } \\
\text { the endogeneity of the uncertainty } \\
\text { measure. }\end{array}$ \\
\hline $\begin{array}{l}\text { Folta, Timothy, and Jonathan P. } \\
\text { O'Brien. "Entry in the Presence of } \\
\text { Dueling Options," Strategic } \\
\text { Management Journal, 2004, 121-138. }\end{array}$ & $\begin{array}{l}\text { Data for } 2,230 \text { US } \\
\text { manufacturing firms from } 1996 \\
\text { to } 2009 \text { and } 17,897 \text { firms from } \\
1980 \text { to } 1999 . \\
\text { Multivariate binomial logit } \\
\text { model }\end{array}$ & $\begin{array}{l}\text { Industry's contribution } \\
\text { to GDP. } \\
\text { Square root of } \\
\text { conditional variance. } \\
\text { GARCH model. }\end{array}$ & $\begin{array}{l}\text { They find the effect of uncertainty on } \\
\text { entry is non-monotonic and U-shaped. } \\
\text { And the turning points are influenced } \\
\text { by factors which should influence } \\
\text { options to grow and defer. Uncertainty } \\
\text { has a potent effect on entry even after } \\
\text { controlling for firm resource profiles, } \\
\text { including the relatedness to the target } \\
\text { industry. }\end{array}$ \\
\hline $\begin{array}{l}\text { Baker, Scott, Nick Bloom and Steven } \\
\text { J. Davis. "Has Economic Policy } \\
\text { Uncertainty Hampered the } \\
\text { Recovery?" Chicago Booth Paper, } \\
\text { No. 12-06, 2012. }\end{array}$ & $\begin{array}{l}\text { Index of economic policy } \\
\text { uncertainty, news-based proxy, } \\
\text { government purchases data, } \\
\text { disagreement about future } \\
\text { indexes from } 1985 \text { to } 2011 \text {. And } \\
\text { tax code expiration data is from } \\
1991 \text { to } 2011 \text {. } \\
\text { VAR model }\end{array}$ & $\begin{array}{l}\text { Merge economic policy } \\
\text { uncertainty, news-based } \\
\text { proxy, government } \\
\text { purchases data and } \\
\text { disagreement about } \\
\text { future indexes into a } \\
\text { new proxy. } \\
\text { Aggregating the above } \\
\text { Components to Obtain } \\
\text { an Index of Economic } \\
\text { Policy Uncertainty }\end{array}$ & $\begin{array}{l}\text { High levels of policy uncertainty in } \\
2010 \text { and } 2011 \text { mainly reflect concerns } \\
\text { about tax and monetary policy. Policy- } \\
\text { related concerns account for a large } \\
\text { share of overall economic uncertainty. A } \\
\text { rise in policy uncertainty is associated } \\
\text { with substantially lower levels of output } \\
\text { and employment compared with that of } \\
\text { actual changes since } 2006 \text {. }\end{array}$ \\
\hline $\begin{array}{l}\text { Driver, Ciaran, Paul Temple and } \\
\text { Giovanni Urga. "Profitability, } \\
\text { capacity, and uncertainty: a model of } \\
\text { UK manufacturing investment," } \\
\text { Oxford Economic Papers, 2005, 120- } \\
141 .\end{array}$ & $\begin{array}{l}\text { Aggregate data of UK } \\
\text { manufacturing on two capital } \\
\text { assets (machinery and building) } \\
\text { from } 1972 \text { to } 1999 . \\
\text { Linear-quadratic model }\end{array}$ & $\begin{array}{l}\text { Output growth. } \\
\text { Time-series conditional } \\
\text { volatility. GARCH } \\
\text { model }\end{array}$ & $\begin{array}{l}\text { The GARCH model shows uncertainty } \\
\text { variable for the full sample are } \\
\text { estimated to be negatively significant at } \\
\text { the } 5 \% \text { level for machinery, and } \\
\text { negative but not significant for building. }\end{array}$ \\
\hline $\begin{array}{l}\text { Greasley, David, and Jakob B. } \\
\text { Madsen. "Investment and } \\
\text { Uncertainty: Precipitating the Great } \\
\text { Depression in the United States," } \\
\text { Economica, 2006, 393-412. }\end{array}$ & $\begin{array}{l}\text { Data of investment information } \\
\text { in US from } 1920 \text { to } 1938 .\end{array}$ & $\begin{array}{l}\text { Real stock prices. } \\
\text { Squared monthly } \\
\text { proportional change. }\end{array}$ & $\begin{array}{l}\text { Effects of uncertainty of the expected } \\
\text { marginal profitability of capital can } \\
\text { explain around } 80 \% \text { of the actual fall in } \\
\text { the business fixed investment ratio in } \\
\text { 1930. Thus, the investment slump } \\
\text { largely led the declines in income. }\end{array}$ \\
\hline $\begin{array}{l}\text { Kilian, Lutz. "Exogenous Oil Supply } \\
\text { Shocks: How Big Are They and How } \\
\text { Much Do They Matter for the U.S. } \\
\text { Economy?" Review of Economics } \\
\text { and Statistics. 2008, 216-240. }\end{array}$ & $\begin{array}{l}\text { Monthly production data for all } \\
\text { OPEC countries and for } \\
\text { aggregate non-OPEC oil } \\
\text { production since } 1973 . \\
\text { OLS }\end{array}$ & $\begin{array}{l}\text { Oil production. } \\
\text { Exogenous variation. }\end{array}$ & $\begin{array}{l}\text { Using new exogenous oil supply shock } \\
\text { measure, it finds statistically significant } \\
\text { evidence of a sharp drop in real GDP } \\
\text { growth and of a spike in CPI inflation } \\
\text { after an exogenous oil supply shock. }\end{array}$ \\
\hline $\begin{array}{l}\text { Guo, Hui, and Kevin L. Kliesen. "Oil } \\
\text { Price Volatility and U.S. } \\
\text { Macroeconomic Activity," Federal } \\
\text { Reserve Bank of St. Louis Review, } \\
\text { 2005, 669-83. }\end{array}$ & $\begin{array}{l}\text { Data of daily price of U.S. 1- } \\
\text { month futures and 12- month } \\
\text { futures contracts from } 1983 \text { to } \\
2004 . \\
\text { Forecasting regression }\end{array}$ & $\begin{array}{l}\text { Oil prices. } \\
\text { Realized variance } \\
\text { series. }\end{array}$ & $\begin{array}{l}\text { Oil price volatility has a negative and } \\
\text { significant effect on future GDP growth } \\
\text { over the period 1984-2004. Moreover, } \\
\text { the effect becomes more significant } \\
\text { after oil price changes are also included } \\
\text { in the regression to control for the } \\
\text { symmetric effect. }\end{array}$ \\
\hline $\begin{array}{l}\text { Elder, John. "Another Perspective on } \\
\text { the Effects of Inflation Uncertainty," } \\
\text { Journal of Money, Credit \& Banking, } \\
\text { 2004, 911-928. }\end{array}$ & $\begin{array}{l}\text { Data of U.S. output growth rate, } \\
\text { inflation, CPI, commodity price } \\
\text { from } 1966 \text { to } 2000 . \\
\text { Cross-section data, }\end{array}$ & $\begin{array}{l}\text { Inflation } \\
\text { Conditional variance. } \\
\text { MGARCH-M VAR } \\
\text { model }\end{array}$ & $\begin{array}{l}\text { Uncertainty about inflation has } \\
\text { significantly reduced real economic } \\
\text { activity over the post-1982 period. One } \\
\text { standard deviation increase in inflation } \\
\text { uncertainty tends to reduce real }\end{array}$ \\
\hline
\end{tabular}




\begin{tabular}{|c|c|c|c|}
\hline & VAR model & & $\begin{array}{l}\text { economic activity by about } 22 \text { basis } \\
\text { points in the post- } 1982 \text { period. }\end{array}$ \\
\hline $\begin{array}{l}\text { Stilianos Fountas, Menelaos } \\
\text { Karanasos and Jinki Kim. "Inflation } \\
\text { Uncertainty, Output Growth } \\
\text { Uncertainty and Macroeconomic } \\
\text { Performance," Oxford Bulletin of } \\
\text { Economics and Statistics. 2006, 319- } \\
\text { 343. }\end{array}$ & $\begin{array}{l}\text { VAR model. Granger-causality } \\
\text { tests }\end{array}$ & $\begin{array}{l}\text { Bivariate GARCH } \\
\text { model. Conditional } \\
\text { variance }\end{array}$ & $\begin{array}{l}\text { First, inflation causes negative welfare } \\
\text { effect. Second, in some countries } \\
\text { (Canada and the UK) more inflation } \\
\text { uncertainty provokes Central Banks to } \\
\text { surprise the public by raising inflation } \\
\text { unexpectedly. Thirdly, More business } \\
\text { cycle variability increases output } \\
\text { growth. }\end{array}$ \\
\hline $\begin{array}{l}\text { Ghosal, Vivek. "Demand Uncertainty } \\
\text { and Capital-Labor Ration: Evidence } \\
\text { from U.S. manufacturing Sector," The } \\
\text { Review of Economics and Statistics, } \\
\text { 1991, 157-161. }\end{array}$ & $\begin{array}{l}\text { Date for } 125 \text { U.S. } \\
\text { manufacturing industries from } \\
1968 \text { to } 1977 . \\
\text { OLS }\end{array}$ & $\begin{array}{l}\text { Fluctuations of } \\
\text { shipments } \\
\text { Standard deviation }\end{array}$ & $\begin{array}{l}\text { There is a significant negative } \\
\text { relationship between demand } \\
\text { uncertainty and the capital-labor ratio, } \\
\text { and that an increase in firm size } \\
\text { counteracts this negative influence. }\end{array}$ \\
\hline $\begin{array}{l}\text { Ghosal, Vivek. "Does uncertainty } \\
\text { influence the number of firms in an } \\
\text { industry?" Economics Letters, 1996, } \\
\text { 229-236. }\end{array}$ & $\begin{array}{l}\text { Date for 196 U.S. industries } \\
\text { from 1973-1986. } \\
\text { IV Estimation }\end{array}$ & $\begin{array}{l}\text { Industry-specific price } \\
\text { Standard deviation of } \\
\text { residuals }\end{array}$ & $\begin{array}{l}\text { Price uncertainty has a statistically } \\
\text { significant and quantitatively large } \\
\text { negative impact on the number of firms } \\
\text { in an industry. }\end{array}$ \\
\hline $\begin{array}{l}\text { Li, Yong. "Duration analysis of } \\
\text { venture capital staging: A real options } \\
\text { perspective," Journal of Business } \\
\text { Venturing, 2008, 497-512. }\end{array}$ & $\begin{array}{l}46,976 \text { portfolio company-round } \\
\text { pairs in U.S. for } 1975-2005, \\
\text { involving } 3737 \text { venture capital } \\
\text { firms and } 15,786 \text { portfolio } \\
\text { companies. } \\
\text { Weibull regression model }\end{array}$ & $\begin{array}{l}\text { Market price volatility; } \\
\text { The stage of } \\
\text { development. } \\
\text { Conditional variance for } \\
\text { market uncertainty } \\
\text { GARCH model }\end{array}$ & $\begin{array}{l}\text { Market uncertainty encourages venture } \\
\text { capital firms to delay investing at each } \\
\text { round of financing, whereas } \\
\text { competition, project-specific } \\
\text { uncertainty and agency concerns } \\
\text { prompt venture capital firms to invest } \\
\text { sooner. }\end{array}$ \\
\hline $\begin{array}{l}\text { Podoynitsyna, Ksenia, Michael Song, } \\
\text { Hans van der Bij and Mathieu } \\
\text { Weggeman. "Improving new } \\
\text { technology venture performance } \\
\text { under direct and indirect network } \\
\text { externality conditions," Journal of } \\
\text { Business Venturing, 2013 195-210. }\end{array}$ & $\begin{array}{l}\text { A sample of } 385 \text { NTVs drawn } \\
\text { from the VentureOne } 2001 \\
\text { database and the 1995-2000 } \\
\text { Inc. } 500 \text { list. } \\
\text { OLS multiple regression }\end{array}$ & $\begin{array}{l}\text { Five main uncertainty } \\
\text { management strategies } \\
\text { Use scales to measure } \\
\text { each of the five } \\
\text { strategies. }\end{array}$ & $\begin{array}{l}\text { They show that real option reasoning } \\
\text { does not always perform better under } \\
\text { conditions of higher uncertainty, such as } \\
\text { uncertainty due to direct network } \\
\text { externalities. }\end{array}$ \\
\hline $\begin{array}{l}\mathrm{Li} \text {, Yong, Joseph T. Mahoney "When } \\
\text { are venture capital projects initiated?" } \\
\text { Journal of Business Venturing, 2011, } \\
\text { 239-254. }\end{array}$ & $\begin{array}{l}\text { Date of venture capital } \\
\text { investment of } 22,164 \text { ventures } \\
\text { made between } 1980 \text { and } 2007 \text { in } \\
\text { the U.S. } \\
\text { Accelerated-failure-time models }\end{array}$ & $\begin{array}{l}\text { Volatility of market } \\
\text { returns. } \\
\text { The standard error of } \\
\text { the regression. }\end{array}$ & $\begin{array}{l}\text { Venture capitalists tend to defer new } \\
\text { investment projects in target industries } \\
\text { with substantial market volatility. This } \\
\text { delay effect is reduced if the target } \\
\text { industry experiences high sales growth } \\
\text { or if competition is intense. }\end{array}$ \\
\hline $\begin{array}{l}\text { Li, Dan. "Multilateral R\&D alliances } \\
\text { by new ventures," Journal of } \\
\text { Business Venturing, 2013, 241-260. }\end{array}$ & $\begin{array}{l}346 \text { new ventures in high- } \\
\text { technology industries from } 1990 \\
\text { to } 2005 . \\
\text { Heckman two-stage regressions. }\end{array}$ & $\begin{array}{l}\text { Mean monthly stock } \\
\text { price volatility. } \\
\text { Standard deviation. }\end{array}$ & $\begin{array}{l}\text { An inverted U-shaped relationship } \\
\text { between market uncertainty and a new } \\
\text { venture's likelihood of forming } \\
\text { multilateral R\&D alliances. }\end{array}$ \\
\hline $\begin{array}{l}\text { Freel, Mark S.. "Perceived } \\
\text { Environmental Uncertainty and } \\
\text { Innovation in Small Firms," Small } \\
\text { Business Economics, 2005, 49-64. }\end{array}$ & $\begin{array}{l}\text { Firm-level survey data of UK } \\
\text { SMEs in } 1996,1998,2000 . \\
\text { Discriminant functions }\end{array}$ & $\begin{array}{l}\text { Supply, finance, } \\
\text { competitors, trade } \\
\text { Asking the firms to } \\
\text { report their feeling of } \\
\text { uncertainty on a five- } \\
\text { point scale. }\end{array}$ & $\begin{array}{l}\text { Higher levels of innovation in } \\
\text { manufacturing firms are associated with } \\
\text { higher perceptions of supplier } \\
\text { uncertainty, whilst, higher levels of } \\
\text { innovation in service firms are } \\
\text { associated with higher perceptions of } \\
\text { human resource uncertainty. }\end{array}$ \\
\hline $\begin{array}{l}\text { Drakos, Konstantinos and Panagiotis } \\
\text { T. Konstantinou. "Investment } \\
\text { Decisions in Manufacturing: } \\
\text { Assessing the Effects of Real Oil } \\
\text { Prices and their Uncertainty," Journal } \\
\text { of Applied Econometrics. 2013, 151- } \\
165 .\end{array}$ & $\begin{array}{l}\text { Data of } 51881 \text { plant-year } \\
\text { observations for Greece for the } \\
\text { period } 1994 \text { to } 2005 . \\
\text { Unbalanced panel data. } \\
\text { Dynamic discrete choice } \\
\text { models. }\end{array}$ & $\begin{array}{l}\text { Real oil price. } \\
\text { Profits. } \\
\text { Daily stock returns } \\
\text { from the Industrials } \\
\text { Price Index. } \\
\text { GARCH model. }\end{array}$ & $\begin{array}{l}\text { Using he CRE estimators of } \\
\text { Wooldridge, they find that that an } \\
\text { increase in measure of real oil price } \\
\text { uncertainty by } 0.01 \text { reduces the } \\
\text { probability of investment action by } 0.46 \\
\text { percent. } \\
\text { Smaller plants are influenced more by } \\
\text { rising real oil-price uncertainty. }\end{array}$ \\
\hline
\end{tabular}




\section{References}

Abel, Andrew. “Optimal Investment under Uncertainty,” American Economic Review, 1983, 228-233.

Appelbaum, Elie, and Eliakim Katz. "Measures of Risk Aversion and Comparative Statics of Industry Equilibrium," American Economic Review, 1986, 524-529.

Association of Chartered Certified Accountants (ACCA). "Small Business: A Global Agenda," ACCA Accountants for Business Report, 2010.

Audretsch, David. Innovation and Industry Evolution. Cambridge: MIT Press, 1995.

Audretsch, David, and Julie Elston. "Does Firm Size Matter? Evidence on the Impact of Liquidity Constraints on Firm Investment Behavior in Germany," International Journal of Industrial Organization, 2002, 1-17.

Audretsch, David, and Julie Elston. "Financing the German Mittelstand," Small Business Economics, 1997, 97-110.

Baker, Scott, Nicholas Bloom and Steven Davis. "Has Economic Policy Uncertainty Hampered the Recovery?" Chicago Booth Paper, No. 12-06, 2012.

Baldwin, John, Guy Gellatly and Valérie Gaudreault. "Financing Innovation in New Small Firms: New Evidence From Canada," Statistics Canada Analytical Studies Series, 2002.

Bianco, Magda, Maria Elena Bontempi, Roberto Golinelli and Giuseppe Parigi. "Family Firms' Investments, Uncertainty and Opacity," Small Business Economics, 2012, 1-24.

Bloom, Nick, Stephen Bond and John van Reenen. "Uncertainty and Investment Dynamics," Review of Economic Studies, 2007, 391-415.

Bo, Hong, and Elmer Sterken. "Volatility of the Interest Rate, Debt and Firm Investment: Dutch Evidence," Journal of Corporate Finance, 2002, 179-193.

Box, G.E.P., and , G.M. Jenkins. Time Series Analysis, Forecasting and Control. San Francisco: Holden Day, 1970.

Carland, J.W., F. Hoy, W. R. Boulton, and J.A.C. Carland, "Differentiating Entrepreneurs from Small Business Owners: A Conceptualization," Academy of Management Review, 1984, 358.

Caves, Richard. "Industrial Organization and New Findings on the Turnover and Mobility of Firms," Journal of Economic Literature, 1998, 1947-1982. 
Campbell, John, and John Cochrane. "By Force of Habit: A Consumption-Based Explanation of Aggregate Stock Market Behavior,” Journal of Political Economy 107, 1999, 205-251.

Delli Gatti, Domenico, Mauro Gallegati, Gianfranco Giulioni and Antonio Palestrini. "Financial Fragility, Patterns of Firms' Entry and Exit and Aggregate Dynamics," Journal of Economic Behavior and Organization 51, 2003, 79-97.

Driver, Ciaran, Paul Temple and Giovanni Urga. "Profitability, Capacity, and Uncertainty: A Model of UK Manufacturing Investment," Oxford Economic Papers, 2005, 120-141.

Driver, Ciaran, and Brendan Whelan. "The Effect of Business Risk on Manufacturing Investment," Journal of Economic Behavior and Organization 44, 2001, 403-412.

Evans, David and Boyan Jovanovic. "An Estimated Model of Entrepreneurial Choice under Liquidity Constraints,” Journal of Political Economy, 1989, 808-827.

Fazzari, Steven, Glenn Hubbard and Bruce Petersen, "Financing Constraints and Corporate Investment." Brookings Papers on Economic Activity, 1988, 141-195.

Federal Reserve Bank of Philadelphia. "Survey of Professional Forecasters."

Folta, Timothy, and Jonathan O'Brien. "Entry in the Presence of Dueling Options," Strategic Management Journal, 2004, 121-138.

Freel, Mark S. "Perceived Environmental Uncertainty and Innovation in Small Firms," Small Business Economics, 2005, 49-64.

Fuss, Catherine, and Philip Vermeulen. "Firms' Investment Decisions in Response to Demand and Price Uncertainty," Applied Economics, 2008, 2337-2351.

Gertler, Mark, and Simon Gilchrist. "Monetary Policy, Business Cycles, and the Behavior of Small Manufacturing Firms," Quarterly Journal of Economics, 1994, 309-340.

Ghosal, Vivek, and Prakash Loungani. "The Differential Impact of Uncertainty on Investment in Small and Large Businesses," Review of Economics and Statistics, 2000, 338-343.

Ghosal, Vivek, and Prakash Loungani. "Product Market Competition and the Impact of Price Uncertainty on Investment: Some Evidence From US Manufacturing Industries," Journal of Industrial Economics, 1996, 217-228.

Ghosal, Vivek. "Does Uncertainty Influence the Number of Firms in an Industry?" Economics Letters 50, 1996, $229-237$.

Ghosal, Vivek. "Demand Uncertainty and the Capital-Labor Ratio: Evidence from the U.S. Manufacturing Sector," Review of Economics and Statistics 73, 1991, 157 - 162. 
Gollier, Christian, and Richard Zeckhauser. "Aggregation of Heterogeneous Time Preferences," Journal of Political Economy 113, 2005, 878-896.

Greasley, David, and Jakob Madsen. "Investment and Uncertainty: Precipitating the Great Depression in the United States," Economica, 2006, 393-412.

Greenwald, Bruce, and Joseph Stiglitz. "Macroeconomic Models with Equity and Credit Rationing," in Hubbard, R. Glenn. ed., Asymmetric Information, Corporate Finance, and Investment. Chicago: University of Chicago Press, 1990, 15-42.

Guo, Hui, and Kevin Kliesen. "Oil Price Volatility and U.S. Macroeconomic Activity," Federal Reserve Bank of St. Louis Review, 2005, 669-83.

Hartman, Richard. "Factor Demand with Output Price Uncertainty," American Economic Review, 1976, 675-681.

Hendry, David, Adrian Pagan and Denis Sargan. "Dynamic Specification," in Zvi Griliches and Michael Intriligator (Eds.), Handbook of Econometrics, Amsterdam: North-Holland, 1983.

Himmelberg, Charles, and Bruce Petersen. "R \& D and Internal Finance: A Panel Study of Small Firms in High-Tech Industries," Review of Economics and Statistics, 1994, 38-51.

Holt Charles, Franco Modigliani, John Muth and Herbert Simon. Planning Production, Inventories and Work Force, Englewood Cliffs: Prentice Hall, 1960.

Hopenhayn, Hugo. "Entry, Exit and Firm Dynamics in Long Run Equilibrium," Econometrica, 1992, 1127-1150.

Huizinga, John. "Inflation Uncertainty, Relative Price Uncertainty, and Investment in U.S. Manufacturing," Journal of Money, Credit and Banking, 1993, 521-549.

Jorgenson, Dale. "Econometric Methods for Modeling Producer Behavior," in Zvi Griliches and Michael Intriligator (Eds.), Handbook of Econometrics, Amsterdam: North Holland, 1986.

Kilian, Lutz. "Exogenous Oil Supply Shocks: How Big Are They and How Much Do They Matter for the U.S. Economy?" Review of Economics and Statistics. 2008, 216-240.

Katz, Jerome, and Richard Green. Entrepreneurial Small Business, McGraw-Hill, 2010.

Koetse, Mark J., Arno J. van der Vlist and Henri L. F. de Groot, "The Impact of Perceived Expectations and Uncertainty on Firm Investment," Small Business Economics, 2006, 365-376.

Kennan, John. "The Estimation of Partial Adjustment Models with Rational Expectations," Econometrica, 1979. 1441-1455. 
Lensink, Robert, Hong Bo and Elmer Sterken Investment. Capital Market Imperfections, and Uncertainty: Theory and Empirical Results. Edgar Elgar, 2001.

Lensink, Robert, Paul van Steen and Elmer Sterken. "Uncertainty and Growth of the Firm," Small Business Economics, 2005, 381-391.

Li, Dan. "Multilateral R\&D Alliances by New Ventures," Journal of Business Venturing, 2013, $241-260$.

Li, Yong. "Duration Analysis of Venture Capital Staging: A Real Options Perspective," Journal of Business Venturing, 2008, 497-512.

Li, Yong, Joseph T. Mahoney "When are venture capital projects initiated?" Journal of Business Venturing, 2011, 239-254.

Lucas, Robert E. “Asset Prices in an Exchange Economy,” Econometrica 46, 1976, 1429-1445.

Marcellino, Massimiliano, James Stock and Mark Watson. "Macroeconomic Forecasting in the Euro Area: Country Specific versus Euro Wide Information," European Economic Review, 2003, 1-18.

Meese, Richard, and John Geweke. "A Comparison of Autoregressive Univariate Forecasting Procedures for Macroeconomic Time Series," Journal of Business and Economic Statistics, 1984, 191-200.

National Economic Council. "The Small Business Agenda: Growing America’s Small Businesses to Win the Future," 2011.

Oriani, Raffaele, and Maurizio Sobrero. "Uncertainty and the Market Valuation of R\&D within a Real Options Logic,” Strategic Management Journal, 2008, 343-361.

Pakes, Ariel, and Richard Ericson. "Empirical Implications of Alternate Models of Firm Dynamics," Journal of Economic Theory, 1998, 1-45.

Podoynitsyna, Ksenia, Michael Song, Hans van der Bij and Mathieu Weggeman. "Improving New Technology Venture Performance under Direct and Indirect Network Externality Conditions," Journal of Business Venturing, 2013 195-210.

Saemundsson, Rognvaldur, and Asa Lindholm Dahlstrand. "How Business Opportunities Constrain Young Technology-Based Firms from Growing into Medium-Sized Firms," Small Business Economics, 2005, 113-129.

Schmitt, John, and Nathan Lane "An International Comparison of Small Business Employment," Center for Economic and Policy Research (CEPR) Reports and Issue Briefs, 2009. 
Sheets, Nathan, and Robert Sockin. "Does Size Really Matter?: The Evolving Role of Small Firms in the U.S. Economy," Empirical \& Thematic Perspectives, Citi Research, 2012.

Stein, Luke, and Elizabeth Stone. "The Effect of Uncertainty on Investment: Evidence from Options," Stanford University Working Paper, 2010.

Sutton, John. “Gibrat’s Legacy,” Journal of Economic Literature, 1997(a), 40-59.

U.S. Small Business Administration. Advocacy: the voice of small business in government. "Frequently Asked Questions about Small Business Finance,"

Winker, Peter. "Causes and Effects of Financing Constraints at the Firm Level," Small Business Economics, 1999, 169-181. 


\section{Figures 1.1-1.4: Growth of employment by size class}

Figure 1.1. Growth of total employment

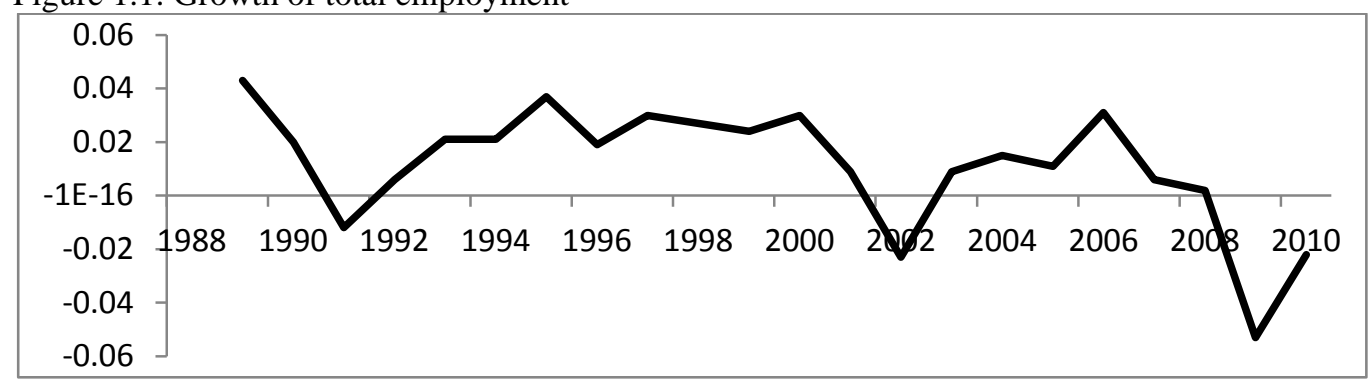

Figure 1.2. Growth of employment in large ( $\geq 500$ employees) businesses

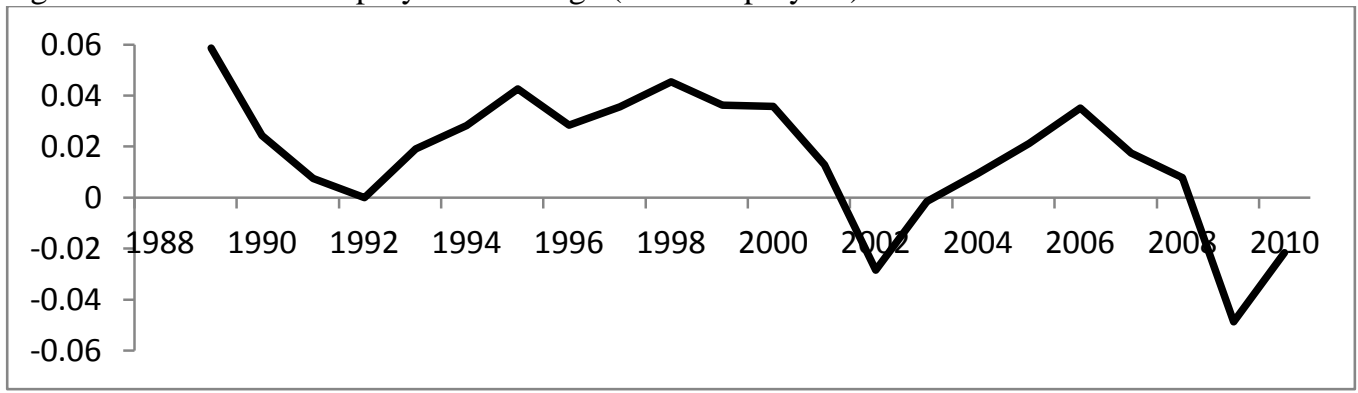

Figure 1.3. Growth of employment in small ( $<500$ employees) businesses

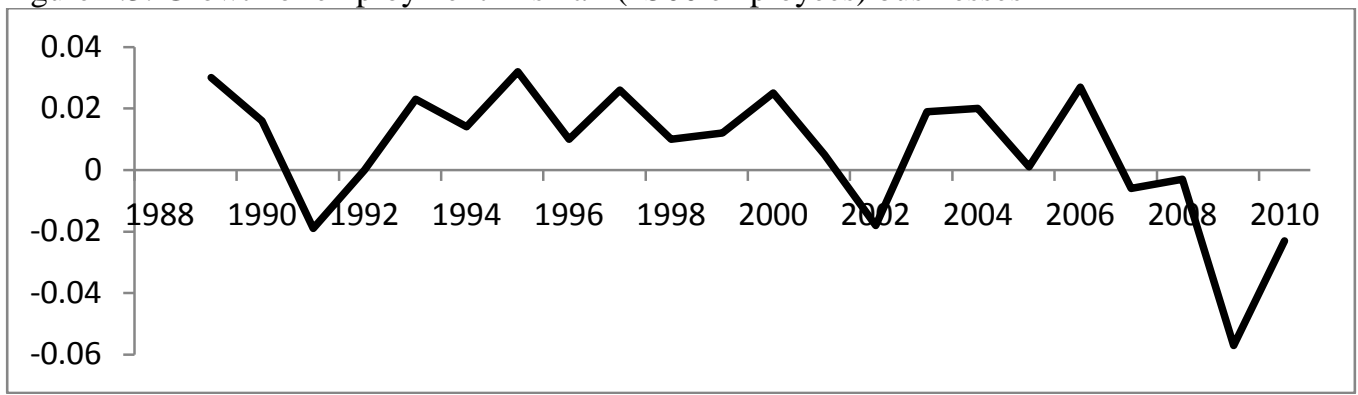

Figure 1.4. Growth of employment in small ( $<20$ employees) businesses




Figures 2.1-2.4: Growth of number of businesses by size class

Figure 2.1. Growth of total number of businesses

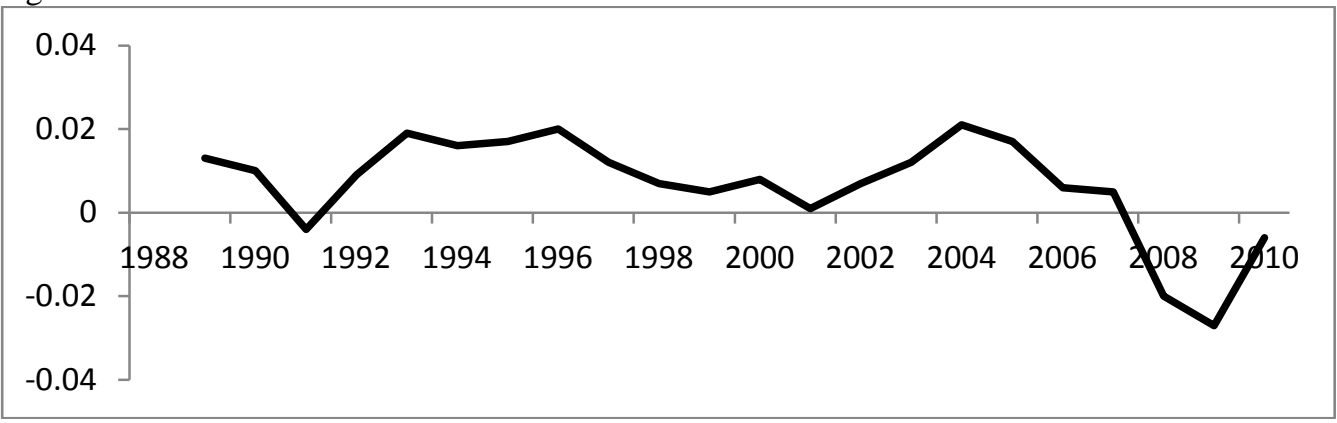

Figure 2.2. Growth of number of large ( $\geq 500$ employees) businesses

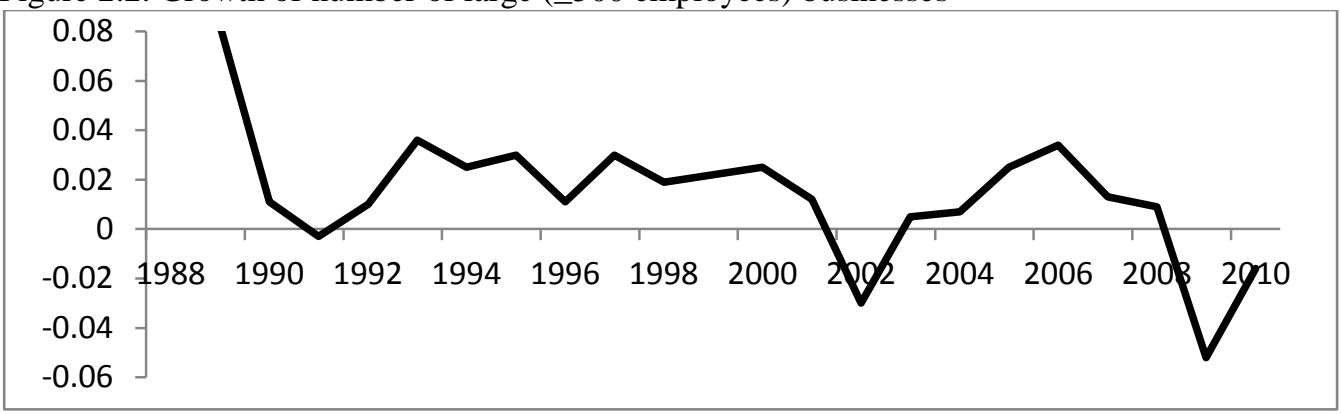

Figure 2.3. Growth of number of small (<500 employees) businesses

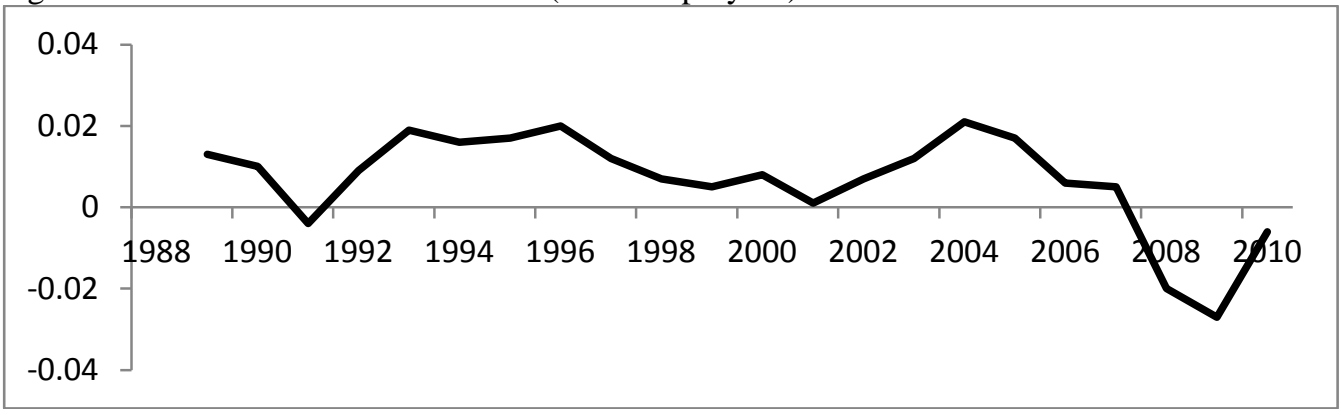

Figure 2.4. Growth of number of small (<20 employees) businesses

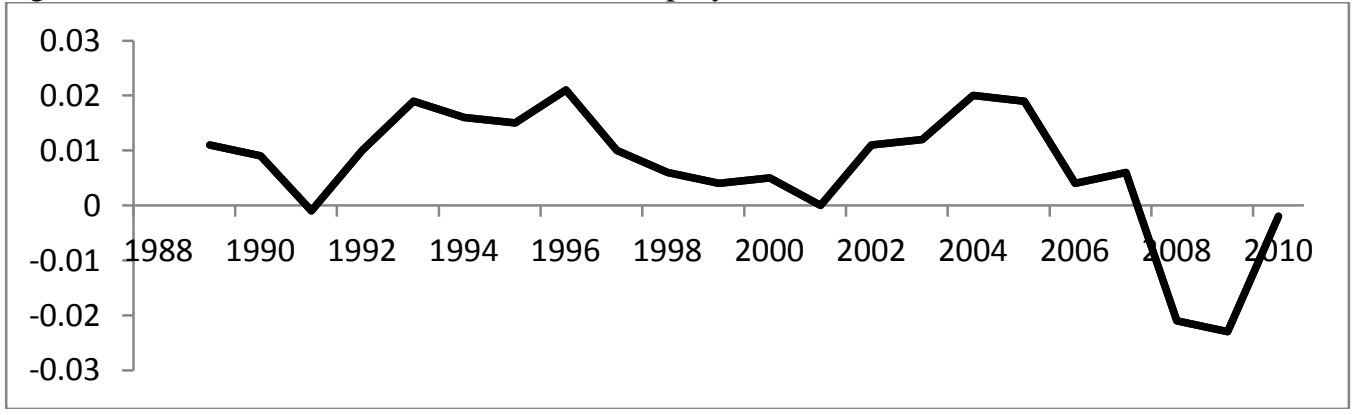




\begin{tabular}{|c|c|c|c|}
\hline \multicolumn{4}{|l|}{ Table 1. Summary statistics } \\
\hline Variable & Mean & Std. Dev. & C.V. \\
\hline \multicolumn{4}{|l|}{ 1. Growth of Employment } \\
\hline $\begin{array}{r}\text { EMP } \\
\text { Size: All }\end{array}$ & 0.01103 & 0.02258 & 204.7 \\
\hline $\begin{array}{r}\text { EMP } \\
\text { Size: Large } w \geq 500 \text { employees }\end{array}$ & 0.01615 & 0.02537 & 157.1 \\
\hline $\begin{array}{r}\text { EMP } \\
\text { Size: Small } w<500 \text { employees }\end{array}$ & 0.00626 & 0.02158 & 344.7 \\
\hline $\begin{array}{r}\text { EMP } \\
\text { Size: Small } w<20 \text { employees }\end{array}$ & 0.00527 & 0.01281 & 243.1 \\
\hline \multicolumn{4}{|l|}{ 2. Growth of Number of Businesses } \\
\hline $\begin{array}{l}\text { FIRMS } \\
\text { Size: } \text { All }\end{array}$ & 0.00664 & 0.01226 & 184.6 \\
\hline $\begin{array}{r}\text { FIRMS } \\
\text { Size: Large } w \geq 500 \text { employees }\end{array}$ & 0.01219 & 0.03188 & 261.5 \\
\hline $\begin{array}{r}\text { FIRMS } \\
\text { Size: Small } w<500 \text { employees }\end{array}$ & 0.00662 & 0.01224 & 338.3 \\
\hline $\begin{array}{r}\text { FIRMS } \\
\text { Size: } \text { Small } w<20 \text { employees } \\
\end{array}$ & 0.00679 & 0.01168 & 172.0 \\
\hline 3. Growth of Real GDP & 0.02550 & 0.01814 & 71.1 \\
\hline \multicolumn{4}{|l|}{ 4. Uncertainty Measures } \\
\hline$\sigma_{s p f g d p, t}^{2}$ & 0.17861 & 0.25266 & 141.4 \\
\hline$\sigma_{\text {spfind }, t}^{2}$ & 0.51206 & 0.73873 & 144.2 \\
\hline$\sigma_{g d p, t}^{2}$ & 0.00027 & 0.00052 & 192.6 \\
\hline$\sigma_{\text {infl,t }}^{2}$ & 0.00003 & 0.00005 & 166.7 \\
\hline$\sigma_{S P 500, t}^{2}$ & 0.01836 & 0.01920 & 104.6 \\
\hline$\sigma_{\text {fuel,t }}^{2}$ & 0.00842 & 0.01281 & 152.1 \\
\hline
\end{tabular}

Notes: C.V. denotes coefficient of variation (percent).

\begin{tabular}{|c|c|c|c|c|c|c|}
\hline & $\sigma_{s p f g d p, t}^{2}$ & $\sigma_{s p f i n d, t}^{2}$ & $\sigma_{g d p, t}^{2}$ & $\sigma_{\text {infl,t }}^{2}$ & $\sigma_{S P 500, t}^{2}$ & $\sigma_{\text {fuel }, t}^{2}$ \\
\hline$\sigma_{s p f g d p, t}^{2}$ & 1.0000 & $\begin{array}{l}0.6543 \\
(0.001)\end{array}$ & $\begin{array}{l}0.7510 \\
(0.001)\end{array}$ & $\begin{array}{l}0.4144 \\
(0.044)\end{array}$ & $\begin{array}{c}0.4083 \\
(0.048)\end{array}$ & $\begin{array}{l}0.4381 \\
(0.032)\end{array}$ \\
\hline$\sigma_{\text {spfind }, t}^{2}$ & $\begin{array}{l}0.6543 \\
(0.001)\end{array}$ & 1.0000 & $\begin{array}{l}0.7772 \\
(0.001)\end{array}$ & $\begin{array}{l}0.6002 \\
(0.002)\end{array}$ & $\begin{array}{r}0.4559 \\
(0.025)\end{array}$ & $\begin{array}{c}0.6358 \\
(0.001)\end{array}$ \\
\hline$\sigma_{g d p, t}^{2}$ & $\begin{array}{r}0.7510 \\
(0.001) \\
\end{array}$ & $\begin{array}{r}0.7772 \\
(0.001) \\
\end{array}$ & 1.0000 & $\begin{array}{l}0.6941 \\
(0.001) \\
\end{array}$ & $\begin{array}{r}0.5501 \\
(0.005) \\
\end{array}$ & $\begin{array}{r}0.6934 \\
(0.001) \\
\end{array}$ \\
\hline$\sigma_{\text {infl,t }}^{2}$ & $\begin{array}{l}0.4144 \\
(0.044)\end{array}$ & $\begin{array}{l}0.6002 \\
(0.002)\end{array}$ & $\begin{array}{l}0.6941 \\
(0.001)\end{array}$ & 1.00000 & $\begin{array}{l}0.4047 \\
(0.050)\end{array}$ & $\begin{array}{l}0.6288 \\
(0.001)\end{array}$ \\
\hline$\sigma_{S P 500, t}^{2}$ & $\begin{array}{l}0.4083 \\
(0.048)\end{array}$ & $\begin{array}{l}0.4559 \\
(0.025)\end{array}$ & $\begin{array}{l}0.5501 \\
(0.005)\end{array}$ & $\begin{array}{l}0.4047 \\
(0.050)\end{array}$ & 1.0000 & $\begin{array}{c}0.3688 \\
(0.076)\end{array}$ \\
\hline$\sigma_{\text {fuel }, t}^{2}$ & $\begin{array}{l}0.4381 \\
(0.032)\end{array}$ & $\begin{array}{c}0.6358 \\
(0.001)\end{array}$ & $\begin{array}{r}0.6934 \\
(0.0002)\end{array}$ & $\begin{array}{l}0.6288 \\
(0.001)\end{array}$ & $\begin{array}{c}0.3688 \\
(0.076)\end{array}$ & 1.0000 \\
\hline
\end{tabular}




\section{Estimation tables.}

Growth of employment specifications: Tables 2.1 and 2.2

Growth of number of businesses specifications: Tables 3.1 and 3.2

\section{Notes for tables 2 and 3 :}

1. p-values (two-tailed test), based on efficient standard errors, are reported in parentheses. An * denotes significance at least at the $10 \%$ level. All specifications are estimated using data over $1988-2011$.

2. The first-order autocorrelation coefficient is denoted by $\rho$.

3. The variable definitions are as follows. (As noted in section 5, the uncertainty terms are measured in logarithms.)

$E M P_{t} \quad=$ Growth (annual percentage change) of employment.

FIRMS $S_{t} \quad$ Growth (annual percentage change) of number of businesses.

$G D P_{t} \quad=$ Growth (annual percentage change) of real GDP.

Survey of Professional Forecasters (SPF) uncertainty measures

$\sigma_{s p f g d p, t}^{2}=$ survey of professional forecasters variance of gdp

$\sigma_{\text {spfind }, t}^{2}=$ survey of professional forecasters variance of industrial (manufacturing) production

Estimation generated uncertainty measures

$\sigma_{g d p, t}^{2} \quad=$ gdp uncertainty.

$\sigma_{\text {infl,t }}^{2} \quad=$ inflation uncertainty

$\sigma_{s p 500, t}^{2} \quad=$ S\&P 500 uncertainty

$\sigma_{\text {fuel,t }}^{2} \quad=$ fuel price uncertainty. 
Table 2.1. Growth of employment specifications. Dependent variable: $E M P_{t}$

\begin{tabular}{|c|c|c|c|c|c|c|c|c|c|c|c|c|}
\hline & \multicolumn{6}{|c|}{$\underline{\text { Size Group: All Businesses }}$} & \multicolumn{6}{|c|}{ Size Group: Large ( $\geq 500$ Employee) Businesses } \\
\hline & S1 & S2 & S3 & S4 & S5 & S6 & S1 & S2 & S3 & S4 & S5 & S6 \\
\hline Const & $\begin{array}{r}-0.0264^{*} \\
(0.001)\end{array}$ & $\begin{array}{r}-0.0273^{*} \\
(0.000)\end{array}$ & $\begin{array}{r}-0.0239^{*} \\
(0.087)\end{array}$ & $\begin{array}{r}-0.0486^{*} \\
(0.023)\end{array}$ & $\begin{array}{r}-0.0314^{*} \\
(0.000)\end{array}$ & $\begin{array}{r}-0.0493^{*} \\
(0.000)\end{array}$ & $\begin{array}{r}-0.0183 * \\
(0.055)\end{array}$ & $\begin{array}{r}-0.0197 * \\
(0.001)\end{array}$ & $\begin{array}{r}-0.0087 \\
(0.653)\end{array}$ & $\begin{array}{r}-0.0555^{*} \\
(0.048)\end{array}$ & $\begin{array}{r}-0.0243^{*} \\
(0.013)\end{array}$ & $\begin{array}{r}-0.0382^{*} \\
(0.001)\end{array}$ \\
\hline$E M P_{t-1}$ & $\begin{array}{r}-0.2261 \\
(0.122) \\
\end{array}$ & $\begin{array}{r}-0.3510^{*} \\
(0.070)\end{array}$ & $\begin{array}{r}-0.3517 * \\
(0.034) \\
\end{array}$ & $\begin{array}{r}-0.4135^{*} \\
(0.048) \\
\end{array}$ & $\begin{array}{r}-0.2208 \\
(0.128) \\
\end{array}$ & $\begin{array}{r}-0.4797 * \\
(0.0142)\end{array}$ & $\begin{array}{l}0.1390 \\
(0.202) \\
\end{array}$ & $\begin{array}{r}0.1867^{*} \\
(0.038)\end{array}$ & $\begin{array}{r}-0.0015 \\
(0.992) \\
\end{array}$ & $\begin{array}{l}0.1216 \\
(0.204)\end{array}$ & $\begin{array}{r}0.1703^{*} \\
(0.041)\end{array}$ & $\begin{array}{c}0.0185 \\
(0.869)\end{array}$ \\
\hline$E M P_{t-2}$ & - & - & - & - & - & - & - & - & - & - & - & - \\
\hline$G D P_{t}$ & $\begin{array}{r}0.5624 * \\
(0.006)\end{array}$ & $\begin{array}{r}0.5110^{*} \\
(0.001)\end{array}$ & $\begin{array}{r}0.6924 * \\
(0.000)\end{array}$ & $\begin{array}{r}0.5858^{*} \\
(0.000)\end{array}$ & $\begin{array}{r}0.5854 * \\
(0.000)\end{array}$ & $\begin{array}{r}0.4492^{*} \\
(0.000)\end{array}$ & $\begin{array}{r}0.6119^{*} \\
(0.009)\end{array}$ & $\begin{array}{r}0.5776^{*} \\
(0.001)\end{array}$ & $\begin{array}{r}0.7452 * \\
(0.000)\end{array}$ & $\begin{array}{r}0.5833^{*} \\
(0.000)\end{array}$ & $\begin{array}{r}0.6129 * \\
(0.000)\end{array}$ & $\begin{array}{r}0.5121 * \\
(0.000)\end{array}$ \\
\hline$G D P_{t-1}$ & $\begin{array}{r}0.7489 * \\
(0.002)\end{array}$ & $\begin{array}{r}0.8648^{*} \\
(0.001)\end{array}$ & $\begin{array}{r}0.8168^{*} \\
(0.002)\end{array}$ & $\begin{array}{r}0.9315^{*} \\
(0.001)\end{array}$ & $\begin{array}{r}0.7659^{*} \\
(0.001)\end{array}$ & $\begin{array}{r}0.9676^{*} \\
(0.000)\end{array}$ & $\begin{array}{r}0.6213^{*} \\
(0.002)\end{array}$ & $\begin{array}{r}0.5711^{*} \\
(0.005)\end{array}$ & $\begin{array}{r}0.6656^{*} \\
(0.003)\end{array}$ & $\begin{array}{r}0.5516^{*} \\
(0.010)\end{array}$ & $\begin{array}{r}0.5674 * \\
(0.003)\end{array}$ & $\begin{array}{r}0.6839^{*} \\
(0.002)\end{array}$ \\
\hline $\ln \sigma_{s p f g d p, t}^{2}$ & $\begin{array}{l}0.0002 \\
(0.950)\end{array}$ & - & - & - & - & - & $\begin{array}{l}0.0010 \\
(0.799)\end{array}$ & - & - & - & - & - \\
\hline $\ln \sigma_{s p f g d p, t-1}^{2}$ & $\begin{array}{r}-0.0025 \\
(0.112)\end{array}$ & - & - & - & - & - & $\begin{array}{l}-0.0008 \\
(0.696)\end{array}$ & - & - & - & - & - \\
\hline $\ln \sigma_{\text {spfind }, t}^{2}$ & - & $\begin{array}{l}-0.0017 \\
(0.221)\end{array}$ & - & - & - & - & - & $\begin{array}{l}-0.0019 \\
(0.237)\end{array}$ & - & - & - & - \\
\hline $\ln \sigma_{\text {spfind }, t-1}^{2}$ & - & $\begin{array}{r}-0.0017 \\
(0.262)\end{array}$ & - & - & - & - & - & $\begin{array}{l}0.0009 \\
(0.613)\end{array}$ & - & - & - & - \\
\hline $\ln \sigma_{g d p, t}^{2}$ & - & - & $\begin{array}{r}0.0030^{*} \\
(0.063)\end{array}$ & - & - & - & - & - & $\begin{array}{l}0.0042 \\
(0.125)\end{array}$ & - & - & - \\
\hline $\ln \sigma_{g d p, t-1}^{2}$ & - & - & $\begin{array}{r}-0.0032^{*} \\
(0.049)\end{array}$ & - & - & - & - & - & $\begin{array}{l}-0.0028 \\
(0.178)\end{array}$ & - & - & - \\
\hline $\ln \sigma_{i n f l, t}^{2}$ & - & - & - & $\begin{array}{l}0.0004 \\
(0.795)\end{array}$ & - & - & - & - & - & $\begin{array}{l}-0.0015 \\
(0.465)\end{array}$ & - & - \\
\hline $\ln \sigma_{\text {infl,t-1}}^{2}$ & - & - & - & $\begin{array}{r}-0.0026^{*} \\
(0.027)\end{array}$ & - & - & - & - & - & $\begin{array}{r}-0.0020^{*} \\
(0.091)\end{array}$ & - & - \\
\hline $\ln \sigma_{s p 500, t}^{2}$ & - & - & - & - & $\begin{array}{r}-0.0004 \\
(0.541)\end{array}$ & - & - & - & - & - & $\begin{array}{l}0.0001 \\
(0.903)\end{array}$ & - \\
\hline $\ln \sigma_{s p 500, t-1}^{2}$ & - & - & - & - & $\begin{array}{r}-0.0014 * \\
(0.099)\end{array}$ & - & - & - & - & - & $\begin{array}{c}-0.0013 \\
(0.158)\end{array}$ & . \\
\hline $\ln \sigma_{\text {fuel }, t}^{2}$ & - & - & - & - & - & $\begin{array}{r}-0.0038^{*} \\
(0.002)\end{array}$ & - & - & - & - & - & $\begin{array}{r}-0.0026^{*} \\
(0.081)\end{array}$ \\
\hline $\ln \sigma_{\text {fuel }, t-1}^{2}$ & - & - & - & - & - & $\begin{array}{r}-0.0017 \\
(0.150)\end{array}$ & - & - & - & - & - & $\begin{array}{r}-0.0017 \\
(0.159)\end{array}$ \\
\hline $\bar{R}^{2}$ & 0.806 & 0.825 & 0.833 & 0.819 & 0.819 & 0.882 & 0.752 & 0.764 & 0.798 & 0.770 & 0.762 & 0.789 \\
\hline$\rho$ & 0.177 & 0.225 & 0.147 & 0.264 & 0.036 & -0.133 & 0.144 & 0.113 & 0.051 & 0.158 & 0.079 & -0.067 \\
\hline
\end{tabular}




\begin{tabular}{|c|c|c|c|c|c|c|c|c|c|c|c|c|}
\hline & \multicolumn{6}{|c|}{ Size Group: Small (<500 Employee) Businesses } & \multicolumn{6}{|c|}{ Size Group: Small (<20 Employee) Businesses } \\
\hline & S1 & S2 & S3 & S4 & S5 & S6 & S1 & S2 & S3 & S4 & S5 & S6 \\
\hline Const & $\begin{array}{r}-0.0359^{*} \\
(0.000)\end{array}$ & $\begin{array}{r}-0.0346^{*} \\
(0.000) \\
\end{array}$ & $\begin{array}{r}-0.0563^{*} \\
(0.000) \\
\end{array}$ & $\begin{array}{r}-0.0687^{*} \\
(0.016) \\
\end{array}$ & $\begin{array}{r}-0.0370^{*} \\
(0.000) \\
\end{array}$ & $\begin{array}{r}-0.0480^{*} \\
(0.000) \\
\end{array}$ & $\begin{array}{r}-0.0192^{*} \\
(0.001) \\
\end{array}$ & $\begin{array}{r}-0.0153^{*} \\
(0.001) \\
\end{array}$ & $\begin{array}{r}-0.0384^{*} \\
(0.000)\end{array}$ & $\begin{array}{r}-0.0279 \\
(0.151) \\
\end{array}$ & $\begin{array}{r}-0.0174 * \\
(0.000) \\
\end{array}$ & $\begin{array}{r}-0.0221^{*} \\
(0.013)\end{array}$ \\
\hline$E M P_{t-1}$ & $\begin{array}{r}-0.4107^{*} \\
(0.012)\end{array}$ & $\begin{array}{r}-0.5815^{*} \\
(0.002)\end{array}$ & $\begin{array}{r}-0.4837^{*} \\
(0.007)\end{array}$ & $\begin{array}{r}-0.5318^{*} \\
(0.018)\end{array}$ & $\begin{array}{r}-0.3907 * \\
(0.042)\end{array}$ & $\begin{array}{r}-0.5465^{*} \\
(0.004)\end{array}$ & $\begin{array}{r}0.0943 \\
(0.594)\end{array}$ & $\begin{array}{r}-0.0239 \\
(0.873)\end{array}$ & $\begin{array}{r}-0.0322 \\
(0.862)\end{array}$ & $\begin{array}{l}0.1030 \\
(0.637)\end{array}$ & $\begin{array}{r}0.1013 \\
(0.581)\end{array}$ & $\begin{array}{r}0.0136 \\
(0.941)\end{array}$ \\
\hline$E M P_{t-2}$ & - & - & - & - & - & - & $\begin{array}{r}-0.2844 * \\
(0.084)\end{array}$ & - & - & - & - & $\begin{array}{r}-0.2754^{*} \\
(0.013)\end{array}$ \\
\hline$G D P_{t}$ & $\begin{array}{r}0.4495^{*} \\
(0.046) \\
\end{array}$ & $\begin{array}{r}0.4492 * \\
(0.001)\end{array}$ & $\begin{array}{r}0.5554 * \\
(0.002) \\
\end{array}$ & $\begin{array}{r}0.5503 * \\
(0.000) \\
\end{array}$ & $\begin{array}{r}0.5806^{*} \\
(0.000) \\
\end{array}$ & $\begin{array}{r}0.4363^{*} \\
(0.001) \\
\end{array}$ & $\begin{array}{r}0.2969^{*} \\
(0.007) \\
\end{array}$ & $\begin{array}{r}0.4223^{*} \\
(0.000) \\
\end{array}$ & $\begin{array}{r}0.3990 * \\
(0.001) \\
\end{array}$ & $\begin{array}{r}0.4519 * \\
(0.000) \\
\end{array}$ & $\begin{array}{r}0.4792^{*} \\
(0.000) \\
\end{array}$ & $\begin{array}{r}0.3781^{*} \\
(0.000)\end{array}$ \\
\hline$G D P_{t-1}$ & $\begin{array}{r}0.7867 * \\
(0.001)\end{array}$ & $\begin{array}{l}0.8903 \\
(0.000)\end{array}$ & $\begin{array}{r}0.7612 * \\
(0.003)\end{array}$ & $\begin{array}{r}0.8475^{*} \\
(0.004)\end{array}$ & $\begin{array}{r}0.7603^{*} \\
(0.003)\end{array}$ & $\begin{array}{r}0.9219^{*} \\
(0.000)\end{array}$ & $\begin{array}{l}0.1232 \\
(0.315)\end{array}$ & $\begin{array}{l}0.0676 \\
(0.532)\end{array}$ & $\begin{array}{l}0.1040 \\
(0.473)\end{array}$ & $\begin{array}{l}0.0551 \\
(0.723)\end{array}$ & $\begin{array}{l}0.0625 \\
(0.671)\end{array}$ & $\begin{array}{r}0.1813 \\
(0.1053) \\
\end{array}$ \\
\hline$\sigma_{s p f g d p, t}^{2}$ & $\begin{array}{r}-0.0014 \\
(0.658)\end{array}$ & - & - & - & - & - & $\begin{array}{r}-0.0028^{*} \\
(0.063)\end{array}$ & - & - & - & - & - \\
\hline$\sigma_{s p f g d p, t-1}^{2}$ & $\begin{array}{r}-0.0039^{*} \\
(0.008)\end{array}$ & - & - & - & - & - & $\begin{array}{r}-0.0031^{*} \\
(0.004)\end{array}$ & - & - & - & - & - \\
\hline$\sigma_{\text {spfind }, t}^{2}$ & - & $\begin{array}{r}-0.0025^{*} \\
(0.051)\end{array}$ & - & - & - & - & - & $\begin{array}{r}-0.0026^{*} \\
(0.001)\end{array}$ & - & - & - & - \\
\hline$\sigma_{\text {spfind }, t-1}^{2}$ & - & $\begin{array}{r}-0.0029 * \\
(0.014)\end{array}$ & - & - & - & - & - & $\begin{array}{r}-0.0015^{*} \\
(0.039)\end{array}$ & - & - & - & - \\
\hline $\ln \sigma_{g d p, t}^{2}$ & - & - & $\begin{array}{l}0.0004 \\
(0.819)\end{array}$ & - & - & - & - & - & $\begin{array}{l}-0.0015 \\
(0.236)\end{array}$ & - & - & - \\
\hline $\ln \sigma_{g d p, t-1}^{2}$ & - & - & $\begin{array}{r}-0.0038^{*} \\
(0.010)\end{array}$ & - & - & - & - & - & $\begin{array}{r}-0.0017 * \\
(0.063)\end{array}$ & - & - & - \\
\hline $\ln \sigma_{i n f l, t}^{2}$ & - & - & - & $\begin{array}{r}-0.0010 \\
(0.594)\end{array}$ & - & - & - & - & - & $\begin{array}{r}-0.0014 \\
(0.208)\end{array}$ & - & - \\
\hline $\ln \sigma_{i n f l, t-1}^{2}$ & - & - & - & $\begin{array}{r}-0.0027 * \\
(0.075) \\
\end{array}$ & - & - & - & - & - & $\begin{array}{r}-0.0003 \\
(0.809)\end{array}$ & - & - \\
\hline $\ln \sigma_{s p 500, t}^{2}$ & - & - & - & - & $\begin{array}{r}-0.0001 \\
(0.861) \\
\end{array}$ & - & - & - & - & - & $\begin{array}{r}-0.0003 \\
(0.562) \\
\end{array}$ & - \\
\hline $\ln \sigma_{s p 500, t-1}^{2}$ & - & - & - & - & $\begin{array}{r}-0.0020 * \\
(0.030) \\
\end{array}$ & - & - & - & - & - & $\begin{array}{r}-0.0012 * \\
(0.036) \\
\end{array}$ & 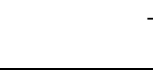 \\
\hline $\ln \sigma_{\text {fuel }, t}^{2}$ & - & - & - & - & - & $\begin{array}{r}-0.0038^{*} \\
(0.003) \\
\end{array}$ & - & - & - & - & - & $\begin{array}{c}-0.0027^{*} \\
(0.0033)\end{array}$ \\
\hline $\ln \sigma_{\text {fuel,t-1}}^{2}$ & - & - & - & - & - & $\begin{array}{r}-0.0006 \\
(0.692)\end{array}$ & & - & - & - & - & $\begin{array}{c}-0.0001 \\
(0.899)\end{array}$ \\
\hline $\bar{R}^{2}$ & 0.749 & 0.796 & 0.773 & 0.741 & 0.755 & 0.795 & 0.745 & 0.768 & 0.724 & 0.629 & 0.667 & 0.754 \\
\hline$\rho$ & 0.124 & 0.134 & 0.241 & 0.213 & 0.111 & 0.160 & 0.001 & 0.063 & 0.117 & 0.066 & 0.113 & 0.095 \\
\hline
\end{tabular}


Table 3.1. Growth of number of businesses specifications. Dependent variable: $F I R M S_{t}$

\begin{tabular}{|c|c|c|c|c|c|c|c|c|c|c|c|c|}
\hline & \multicolumn{6}{|c|}{ Size Group: All Businesses } & \multicolumn{6}{|c|}{ Size Group: Large ( $\geq 500$ Employee) Businesses } \\
\hline & S1 & S2 & S3 & S4 & S5 & S6 & S1 & S2 & S3 & S4 & S5 & S6 \\
\hline Const & $\begin{array}{r}-0.0092^{*} \\
(0.048)\end{array}$ & $\begin{array}{r}-0.0063^{*} \\
(0.032)\end{array}$ & $\begin{array}{r}-0.0160 \\
(0.123)\end{array}$ & $\begin{array}{r}-0.0164 \\
(0.313)\end{array}$ & $\begin{array}{r}-0.0069 \\
(0.127)\end{array}$ & $\begin{array}{r}-0.0060 \\
(0.230)\end{array}$ & $\begin{array}{l}0.0094 \\
(0.335)\end{array}$ & $\begin{array}{c}-0.0028 \\
(0.662)\end{array}$ & $\begin{array}{r}0.0637 * \\
(0.069)\end{array}$ & $\begin{array}{l}-0.0031 \\
(0.950)\end{array}$ & $\begin{array}{r}-0.0147 \\
(0.146)\end{array}$ & $\begin{array}{r}-0.0416^{*} \\
(0.011)\end{array}$ \\
\hline$F I R M S_{t-1}$ & $\begin{array}{r}0.5036^{*} \\
(0.002) \\
\end{array}$ & $\begin{array}{r}0.4814^{*} \\
(0.002)\end{array}$ & $\begin{array}{r}0.5472 * \\
(0.002) \\
\end{array}$ & $\begin{array}{r}0.6427^{*} \\
(0.002)\end{array}$ & $\begin{array}{r}0.7189 * \\
(0.000) \\
\end{array}$ & $\begin{array}{r}0.6887 * \\
(0.001) \\
\end{array}$ & $\begin{array}{r}-0.5427^{*} \\
(0.004)\end{array}$ & $\begin{array}{r}-0.5486^{*} \\
(0.010) \\
\end{array}$ & $\begin{array}{r}-0.7865^{*} \\
(0.000)\end{array}$ & $\begin{array}{r}-0.6529^{*} \\
(0.003) \\
\end{array}$ & $\begin{array}{r}-0.6209^{*} \\
(0.001)\end{array}$ & $\begin{array}{r}-0.6841^{*} \\
(0.006)\end{array}$ \\
\hline$F I R M S_{t-2}$ & - & - & - & - & $\begin{array}{r}-0.2926^{*} \\
(0.091)\end{array}$ & $\begin{array}{r}-0.3689^{*} \\
(0.076)\end{array}$ & $\begin{array}{r}-0.5930 * \\
(0.003)\end{array}$ & $\begin{array}{r}-0.5324^{*} \\
(0.020)\end{array}$ & $\begin{array}{r}-0.8287^{*} \\
(0.000)\end{array}$ & $\begin{array}{r}-0.6838^{*} \\
(0.001)\end{array}$ & $\begin{array}{r}-0.6059^{*} \\
(0.004)\end{array}$ & $\begin{array}{r}-0.6216^{*} \\
(0.002)\end{array}$ \\
\hline$G D P_{t}$ & $\begin{array}{r}0.3372 * \\
(0.000)\end{array}$ & $\begin{array}{r}0.4158^{*} \\
(0.000)\end{array}$ & $\begin{array}{r}0.3138^{*} \\
(0.000)\end{array}$ & $\begin{array}{r}0.3759^{*} \\
(0.001)\end{array}$ & $\begin{array}{r}0.3615^{*} \\
(0.000)\end{array}$ & $\begin{array}{r}0.3713^{*} \\
(0.000)\end{array}$ & $\begin{array}{l}0.0102 \\
(0.962)\end{array}$ & $\begin{array}{r}1.2435^{*} \\
(0.001)\end{array}$ & $\begin{array}{l}0.1012 \\
(0.679)\end{array}$ & $\begin{array}{r}-0.1945 \\
(0.273)\end{array}$ & $\begin{array}{r}-0.1520 \\
(0.432)\end{array}$ & $\begin{array}{r}-0.3017^{*} \\
(0.067)\end{array}$ \\
\hline$G D P_{t-1}$ & $\begin{array}{r}-0.1230 \\
(0.180)\end{array}$ & $\begin{array}{r}-0.2085^{*} \\
(0.014)\end{array}$ & $\begin{array}{r}-0.1248 \\
(0.167)\end{array}$ & $\begin{array}{r}-0.2603^{*} \\
(0.009)\end{array}$ & $\begin{array}{r}-0.1501 * \\
(0.065)\end{array}$ & $\begin{array}{r}-0.1300 \\
(0.176)\end{array}$ & $\begin{array}{r}1.1062^{*} \\
(0.003)\end{array}$ & - & $\begin{array}{r}1.4109^{*} \\
(0.000)\end{array}$ & $\begin{array}{r}1.3490^{*} \\
(0.000)\end{array}$ & $\begin{array}{r}1.1398^{*} \\
(0.001)\end{array}$ & $\begin{array}{r}1.1186^{*} \\
(0.000)\end{array}$ \\
\hline $\ln \sigma_{s p f g d p, t}^{2}$ & $\begin{array}{r}-0.0024^{*} \\
(0.076)\end{array}$ & - & - & - & - & - & $\begin{array}{r}0.0067^{*} \\
(0.074)\end{array}$ & - & - & - & - & - \\
\hline $\ln \sigma_{s p f g d p, t-1}^{2}$ & $\begin{array}{r}-0.0001 \\
(0.956)\end{array}$ & - & - & - & - & - & $\begin{array}{l}-0.0028 \\
(0.569)\end{array}$ & - & - & - & - & - \\
\hline $\ln \sigma_{\text {spfind }, t}^{2}$ & - & $\begin{array}{r}-0.0020^{*} \\
(0.016)\end{array}$ & - & - & - & - & - & $\begin{array}{r}0.0032 \\
(0.1604)\end{array}$ & - & - & - & - \\
\hline $\ln \sigma_{\text {spfind }, t-1}^{2}$ & - & $\begin{array}{r}-0.0000 \\
(0.966)\end{array}$ & - & - & - & - & - & $\begin{array}{r}-0.0046 \\
(0.1607)\end{array}$ & - & - & - & - \\
\hline $\ln \sigma_{g d p, t}^{2}$ & - & - & $\begin{array}{r}-0.0025^{*} \\
(0.008)\end{array}$ & - & - & - & - & - & $\begin{array}{r}0.0093^{*} \\
(0.008)\end{array}$ & - & - & - \\
\hline $\ln \sigma_{g d p, t-1}^{2}$ & - & - & $\begin{array}{l}0.0010 \\
(0.381)\end{array}$ & - & - & - & - & - & $\begin{array}{l}-0.0020 \\
(0.553)\end{array}$ & - & - & - \\
\hline $\ln \sigma_{i n f l, t}^{2}$ & - & - & - & $\begin{array}{r}-0.0019^{*} \\
(0.034)\end{array}$ & - & - & - & - & - & $\begin{array}{l}0.0018 \\
(0.673)\end{array}$ & - & - \\
\hline $\ln \sigma_{\text {infl,t-1}}^{2}$ & - & - & - & $\begin{array}{l}0.0006 \\
(0.551)\end{array}$ & - & - & - & - & - & $\begin{array}{l}-0.0021 \\
(0.529)\end{array}$ & - & - \\
\hline $\ln \sigma_{s p 500, t}^{2}$ & - & - & - & - & $\begin{array}{r}-0.0009 * \\
(0.085)\end{array}$ & - & - & - & - & - & $\begin{array}{l}0.0001 \\
(0.971)\end{array}$ & - \\
\hline $\ln \sigma_{s p 500, t-1}^{2}$ & - & - & - & - & $\begin{array}{r}-0.0002 \\
(0.737)\end{array}$ & - & - & - & - & - & $\begin{array}{r}-0.0035^{*} \\
(0.025)\end{array}$ & - \\
\hline $\ln \sigma_{\text {fuel }, t}^{2}$ & - & - & - & - & - & $\begin{array}{r}-0.0012 \\
(0.107)\end{array}$ & - & - & - & - & - & $\begin{array}{r}-0.0060^{*} \\
(0.028)\end{array}$ \\
\hline $\ln \sigma_{\text {fuel }, t-1}^{2}$ & & - & - & - & - & $\begin{array}{l}0.0003 \\
(0.806)\end{array}$ & - & - & - & - & - & $\begin{array}{l}-0.0037 \\
(0.255)\end{array}$ \\
\hline $\bar{R}^{2}$ & 0.709 & 0.736 & 0.748 & 0.726 & 0.715 & 0.707 & 0.447 & 0.470 & 0.556 & 0.400 & 0.462 & 0.556 \\
\hline$\rho$ & 0.119 & 0.028 & 0.013 & 0.013 & -0.106 & -0.174 & 0.241 & 0.323 & 0.135 & 0.248 & 0.151 & 0.100 \\
\hline
\end{tabular}


Table 3.2. Growth of number of businesses specifications. Dependent variable: FIRMS $_{t}$

\begin{tabular}{|c|c|c|c|c|c|c|c|c|c|c|c|c|}
\hline & \multicolumn{6}{|c|}{ Size Group: Small (<500 Employee) Businesses } & \multicolumn{6}{|c|}{ Size Group: Small (<20 Employee) Businesses } \\
\hline & S1 & $\mathrm{S} 2$ & S3 & S4 & S5 & \begin{tabular}{|l|} 
S6 \\
\end{tabular} & S1 & S2 & \begin{tabular}{|l|} 
S3 \\
\end{tabular} & S4 & \begin{tabular}{|l|} 
S5 \\
\end{tabular} & S6 \\
\hline Const & $\begin{array}{r}-0.0091^{*} \\
(0.049) \\
\end{array}$ & $\begin{array}{r}-0.0062^{*} \\
(0.033) \\
\end{array}$ & $\begin{array}{r}-0.0157 \\
(0.129) \\
\end{array}$ & $\begin{array}{r}-0.0159 \\
(0.318) \\
\end{array}$ & $\begin{array}{r}-0.0067 \\
(0.128) \\
\end{array}$ & $\begin{array}{r}-0.0057 \\
(0.245) \\
\end{array}$ & $\begin{array}{r}-0.0077 \\
(0.137) \\
\end{array}$ & $\begin{array}{r}-0.0048 \\
(0.185) \\
\end{array}$ & $\begin{array}{r}-0.0153 \\
(0.259) \\
\end{array}$ & $\begin{array}{r}-0.0201 \\
(0.3203) \\
\end{array}$ & $\begin{array}{r}-0.0079 \\
(0.152) \\
\end{array}$ & $\begin{array}{r}-0.0044 \\
(0.371) \\
\end{array}$ \\
\hline$F I R M S_{t-1}$ & $\begin{array}{l}0.515^{*} \\
(0.001) \\
\end{array}$ & $\begin{array}{r}0.4919^{*} \\
(0.002) \\
\end{array}$ & $\begin{array}{r}0.5591^{*} \\
(0.002) \\
\end{array}$ & $\begin{array}{r}0.6506^{*} \\
(0.002) \\
\end{array}$ & $\begin{array}{r}0.7356^{*} \\
(0.000) \\
\end{array}$ & $\begin{array}{r}0.7052^{*} \\
(0.000) \\
\end{array}$ & $\begin{array}{r}0.4558^{*} \\
(0.011) \\
\end{array}$ & $\begin{array}{r}0.4012 * \\
(0.032) \\
\end{array}$ & $\begin{array}{r}0.4619^{*} \\
(0.032) \\
\end{array}$ & $\begin{array}{r}0.5159^{*} \\
(0.027)\end{array}$ & $\begin{array}{r}0.4710^{*} \\
(0.013)\end{array}$ & $\begin{array}{r}0.4802 * \\
(0.021)\end{array}$ \\
\hline$F I R M S_{t-2}$ & - & - & - & - & $\begin{array}{r}-0.3007^{*} \\
(0.074)\end{array}$ & $\begin{array}{r}-0.3720^{*} \\
(0.070)\end{array}$ & - & - & - & 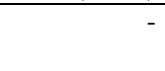 & - & - \\
\hline$G D P_{t}$ & $\begin{array}{r}0.3340 * \\
(0.000)\end{array}$ & $\begin{array}{r}0.4126^{*} \\
(0.000)\end{array}$ & $\begin{array}{r}0.3103^{*} \\
(0.000)\end{array}$ & $\begin{array}{r}0.3740^{*} \\
(0.001)\end{array}$ & $\begin{array}{r}0.3576^{*} \\
(0.000)\end{array}$ & $\begin{array}{l}0.3686 \\
(0.158)\end{array}$ & $\begin{array}{r}0.2765^{*} \\
(0.001)\end{array}$ & $\begin{array}{r}0.3774 * \\
(0.001)\end{array}$ & $\begin{array}{r}0.2638^{*} \\
(0.004)\end{array}$ & $\begin{array}{r}0.3454 * \\
(0.007)\end{array}$ & $\begin{array}{l}0.3806^{*} \\
(0.0008)\end{array}$ & $\begin{array}{r}0.3760^{*} \\
(0.001)\end{array}$ \\
\hline$G D P_{t-1}$ & $\begin{array}{r}-0.1266 \\
(0.162)\end{array}$ & $\begin{array}{r}-0.2116^{*} \\
(0.013)\end{array}$ & $\begin{array}{r}-0.1274 \\
(0.154)\end{array}$ & $\begin{array}{r}-0.2609^{*} \\
(0.008)\end{array}$ & $\begin{array}{r}-0.1529 * \\
(0.056)\end{array}$ & $\begin{array}{r}-0.1345 \\
(0.158)\end{array}$ & $\begin{array}{r}-0.1061 \\
(0.288)\end{array}$ & $\begin{array}{r}-0.2085^{*} \\
(0.011)\end{array}$ & $\begin{array}{r}-0.1073 \\
(0.274)\end{array}$ & $\begin{array}{r}-0.2434 * \\
(0.014)\end{array}$ & $\begin{array}{r}-0.1897 * \\
(0.023)\end{array}$ & $\begin{array}{r}-0.1755^{*} \\
(0.053)\end{array}$ \\
\hline$\sigma_{s p f g d p, t}^{2}$ & $\begin{array}{r}-0.0024^{*} \\
(0.075)\end{array}$ & - & - & - & - & - & $\begin{array}{r}-0.0030^{*} \\
(0.057)\end{array}$ & - & - & - & - & - \\
\hline$\sigma_{s p f g d p, t-1}^{2}$ & $\begin{array}{r}-0.0001 \\
(0.961)\end{array}$ & - & - & - & - & - & $\begin{array}{l}0.0005 \\
(0.691)\end{array}$ & - & - & - & - & - \\
\hline$\sigma_{\text {spfind }, t}^{2}$ & - & $\begin{array}{r}-0.0020^{*} \\
(0.017)\end{array}$ & - & - & - & - & - & $\begin{array}{c}-0.0020^{*} \\
(0.0513)\end{array}$ & - & - & - & - \\
\hline$\sigma_{\text {spfind }, t-1}^{2}$ & - & $\begin{array}{l}-0.0000 \\
(0.966)\end{array}$ & - & - & - & - & - & $\begin{array}{r}-0.0002 \\
(0.801)\end{array}$ & - & - & - & - \\
\hline $\ln \sigma_{g d p, t}^{2}$ & - & - & $\begin{array}{r}-0.0025^{*} \\
(0.008)\end{array}$ & - & - & - & - & - & $\begin{array}{r}-0.0027^{*} \\
(0.008)\end{array}$ & - & - & 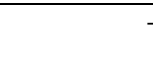 \\
\hline $\ln \sigma_{g d p, t-1}^{2}$ & - & - & $\begin{array}{l}0.0011 \\
(0.366)\end{array}$ & - & - & - & - & - & $\begin{array}{l}0.0012 \\
(0.382)\end{array}$ & - & - & - \\
\hline $\ln \sigma_{i n f l, t}^{2}$ & - & - & - & $\begin{array}{r}-0.0019^{*} \\
(0.039)\end{array}$ & - & - & - & - & - & $\begin{array}{r}-0.0020 * \\
(0.062)\end{array}$ & - & - \\
\hline $\ln \sigma_{\text {infl,t-1}}^{2}$ & - & - & - & $\begin{array}{l}0.0006 \\
(0.555)\end{array}$ & - & - & - & - & - & $\begin{array}{l}0.0002 \\
(0.863)\end{array}$ & - & - \\
\hline $\ln \sigma_{s p 500, t}^{2}$ & - & - & - & - & $\begin{array}{c}-0.0009^{*} \\
(0.081)\end{array}$ & - & - & - & - & - & $\begin{array}{r}-0.0005 \\
(0.438)\end{array}$ & 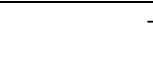 \\
\hline $\ln \sigma_{s p 500, t-1}^{2}$ & - & - & - & - & $\begin{array}{r}-0.0002 \\
(0.763)\end{array}$ & - & - & - & - & - & $\begin{array}{r}-0.0007 \\
(0.260)\end{array}$ & 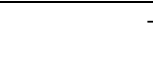 \\
\hline $\ln \sigma_{\text {fuel,t }}^{2}$ & - & - & - & - & - & $\begin{array}{l}-0.0011 \\
(0.105)\end{array}$ & - & - & - & - & - & $\begin{array}{r}-0.0006 \\
(0.531)\end{array}$ \\
\hline $\ln \sigma_{\text {fuel, }, t-1}^{2}$ & & - & - & - & - & $\begin{array}{l}0.0003 \\
(0.781)\end{array}$ & - & - & - & - & - & $\begin{array}{c}0.0001 \\
(0.929)\end{array}$ \\
\hline $\bar{R}^{2}$ & 0.712 & 0.738 & 0.750 & 0.726 & 0.719 & 0.711 & 0.606 & 0.609 & 0.637 & 0.594 & 0.575 & 0.545 \\
\hline$\rho$ & 0.126 & 0.034 & 0.017 & 0.021 & -0.107 & -0.178 & -0.024 & -0.090 & -0.110 & -0.099 & -0.056 & -0.032 \\
\hline
\end{tabular}




\begin{tabular}{|c|c|c|c|c|c|c|c|c|c|c|c|c|}
\hline & & & $\begin{array}{l}\text { Size Group: } \\
\text { growth of }\end{array}$ & $\begin{array}{l}\text { Businesses } \\
\text { oyment }=0 .\end{array}$ & & & & $\frac{\text { Size C }}{1}$ & $\begin{array}{l}\text { : Large }(\geq 5 \\
\text { growth of }\end{array}$ & $\begin{array}{l}\text { mployee) } 1 \\
\text { loyment }=0 \text {. }\end{array}$ & esses & \\
\hline & S1 & S2 & S3 & S4 & S5 & S6 & S1 & S2 & S3 & S4 & S5 & S6 \\
\hline$G D P_{t}$ & $0.0101 *$ & $0.0092 *$ & $0.0125^{*}$ & $0.0105^{*}$ & $0.0105^{*}$ & $0.0081^{*}$ & $0.0110^{*}$ & $0.0104^{*}$ & $0.0134^{*}$ & $0.0105^{*}$ & $0.0110^{*}$ & $0.0092 *$ \\
\hline$G D P_{t-1}$ & $0.0135^{*}$ & $0.0156^{*}$ & $0.0147^{*}$ & $0.0167^{*}$ & $0.0138^{*}$ & $0.0174 *$ & $0.0112^{*}$ & $0.0103^{*}$ & $0.0119^{*}$ & $0.0099^{*}$ & $0.0102^{*}$ & $0.0123 *$ \\
\hline$\overline{\sigma_{s p f g d p, t}^{2}}$ & 0.0003 & - & - & - & - & - & 0.0014 & - & - & - & - & - \\
\hline$\sigma_{s p f g d p, t-1}^{2}$ & -0.0036 & - & - & - & - & - & -0.0011 & - & - & - & - & - \\
\hline$\overline{\sigma_{\text {spfind }, t}^{2}}$ & - & -0.0024 & - & - & - & - & - & -0.0027 & - & - & - & - \\
\hline$\overline{\sigma_{\text {spfind }, t-1}^{2}}$ & - & -0.0023 & - & - & - & - & - & 0.0013 & - & - & - & - \\
\hline$\overline{\sigma_{g d p, t}^{2}}$ & - & - & $0.0058^{*}$ & - & - & - & - & - & 0.0081 & - & - & - \\
\hline$\overline{\sigma_{g d p, t-1}^{2}}$ & - & - & $-0.0062 *$ & - & - & - & - & - & -0.0054 & - & - & - \\
\hline$\overline{\sigma_{i n f l, t}^{2}}$ & - & - & - & 0.0007 & - & - & - & - & - & -0.0025 & - & - \\
\hline$\overline{\sigma_{i n f l, t-1}^{2}}$ & - & - & - & $-0.0043^{*}$ & - & - & - & - & - & $-0.0033^{*}$ & - & - \\
\hline$\overline{\sigma_{s p 500, t}^{2}}$ & - & - & - & - & -0.0004 & - & - & - & - & - & 0.0001 & - \\
\hline$\overline{\sigma_{s p 500, t-1}^{2}}$ & - & - & - & - & $-0.0015^{*}$ & - & - & - & - & - & -0.0013 & - \\
\hline$\overline{\sigma_{\text {fuel }, t}^{2}}$ & - & - & - & - & - & $-0.0058^{*}$ & - & - & - & - & - & $-0.0039 *$ \\
\hline$\sigma_{\text {fuel }, t-1}^{2}$ & - & - & - & - & - & -0.0026 & - & - & - & - & - & -0.0026 \\
\hline
\end{tabular}

Notes:

1.The reported numbers above measure the effect of a one-standard-deviation increase in the relevant independent variable on growth of employment by size category. See section 7.2 for details.

2. An asterisk denotes that the estimated effect is significant at least at the $10 \%$ level (see notes to tables 2 and 3 ).

3. To keep the tables more compact, the effects of lagged dependent variable are not reported. For each specification's regression statistics $\left(\bar{R}^{2}\right.$ and $\left.\rho\right)$, see tables 2 and 3 . 


\begin{tabular}{|c|c|c|c|c|c|c|c|c|c|c|c|c|}
\hline & & $\frac{\text { Size C }}{1}$ & $\begin{array}{l}\text { oup: Small }(<5 \\
\text { lean growth of }\end{array}$ & $\begin{array}{l}0 \text { Employee) } \\
\text { mployment }=0\end{array}$ & $\begin{array}{l}\text { 3usinesses } \\
0063\end{array}$ & & & $\frac{\text { Size }}{1}$ & $\begin{array}{l}\text { roup: Small (< } \\
\text { lean growth of }\end{array}$ & $\begin{array}{l}0 \text { Employee) } \mathrm{Br} \\
\text { mployment }=0.0\end{array}$ & $\begin{array}{l}\text { isinesses } \\
053\end{array}$ & \\
\hline & S1 & S2 & S3 & S4 & S5 & S6 & S1 & S2 & S3 & S4 & S5 & S6 \\
\hline$G D P_{t}$ & $0.0081 *$ & $0.0081^{*}$ & $0.0099^{*}$ & $0.0098^{*}$ & $0.0104 *$ & $0.0078^{*}$ & $0.0053^{*}$ & $0.0076^{*}$ & $0.0072 *$ & $0.0082 *$ & $0.0086^{*}$ & $0.0068 *$ \\
\hline$G D P_{t-1}$ & $0.0142 *$ & 0.0160 & $0.0137^{*}$ & $0.0152 *$ & $0.0137 *$ & $0.0166^{*}$ & 0.0022 & 0.0012 & 0.0018 & 0.0009 & 0.0011 & 0.0033 \\
\hline$\sigma_{s p f g d p, t}^{2}$ & -0.0019 & - & - & - & - & - & $-0.0039^{*}$ & - & - & - & - & - \\
\hline$\sigma_{s p f g d p, t-1}^{2}$ & $-0.0051^{*}$ & - & - & - & - & - & $-0.0044 *$ & - & - & - & - & - \\
\hline$\sigma_{\text {spfind }, t}^{2}$ & - & $-0.0036^{*}$ & - & - & - & - & - & $-0.0037^{*}$ & - & - & - & - \\
\hline$\sigma_{\text {spfind }, t-1}^{2}$ & - & $-0.0042 *$ & - & - & - & - & - & $-0.0021^{*}$ & - & - & - & - \\
\hline$\sigma_{g d p, t}^{2}$ & - & - & 0.0008 & - & - & - & - & - & $\begin{array}{l}-0.0029 \\
\end{array}$ & - & - & - \\
\hline$\sigma_{g d p, t-1}^{2}$ & - & - & $-0.0074 *$ & - & - & - & - & - & $-0.0033^{*}$ & - & - & - \\
\hline$\sigma_{\text {infl,t }}^{2}$ & - & - & - & -0.0017 & - & - & - & - & - & -0.0023 & - & - \\
\hline$\sigma_{\text {infl,t-1 }}^{2}$ & - & - & - & $-0.0045^{*}$ & - & - & - & - & - & -0.0005 & - & - \\
\hline$\sigma_{s p 500, t}^{2}$ & - & - & - & - & -0.0001 & - & - & - & - & - & -0.0003 & \\
\hline$\sigma_{s p 500, t-1}^{2}$ & - & - & - & - & $-0.0021^{*}$ & - & - & - & - & - & $-0.0012^{*}$ & \\
\hline$\sigma_{\text {fuel,t }}^{2}$ & - & - & - & - & - & $-0.0058^{*}$ & - & - & - & - & - & $-0.0041^{*}$ \\
\hline$\sigma_{\text {fuel,t-1}}^{2}$ & - & - & - & - & - & -0.0009 & & - & - & - & - & -0.0001 \\
\hline
\end{tabular}

Notes:

1.The reported numbers above measure the effect of a one-standard-deviation increase in the relevant independent variable on growth of employment by size category. See section 7.2 for details.

2. An asterisk denotes that the estimated effect is significant at least at the $10 \%$ level (see notes to tables 2 and 3 ).

3. To keep the tables more compact, the effects of lagged dependent variable are not reported. For each specification's regression statistics $\left(\bar{R}^{2}\right.$ and $\left.\rho\right)$, see tables 2 and 3 . 
Table 5.1. Growth of number of businesses specifications

Dependent variable: $F I R M S_{t}$

Quantitative effect of one-s.d. increase in driving variable

\begin{tabular}{|c|c|c|c|c|c|c|c|c|c|c|c|c|}
\hline & \multicolumn{6}{|c|}{$\begin{array}{l}\text { Size Group: All Businesses } \\
\text { Mean growth of number of businesses }=0.0066\end{array}$} & \multicolumn{6}{|c|}{$\begin{array}{l}\text { Size Group: Large ( } \geq 500 \text { Employee) Businesses } \\
\text { Mean growth of number of businesses }=0.0122\end{array}$} \\
\hline & S1 & S2 & S3 & S4 & S5 & S6 & S1 & S2 & S3 & S4 & S5 & S6 \\
\hline$G D P_{t}$ & $0.0060 *$ & $0.0075^{*}$ & $0.0056^{*}$ & $0.0067^{*}$ & $0.0065^{*}$ & $0.0067^{*}$ & 0.0002 & $0.0223 *$ & 0.0018 & -0.0035 & -0.0027 & $-0.0054 *$ \\
\hline$G D P_{t-1}$ & -0.0022 & $-0.0037 *$ & -0.0022 & $-0.0047 *$ & $-0.0027 *$ & -0.0023 & $0.0199 *$ & & $0.0254 *$ & $0.0243 *$ & $0.0205^{*}$ & $0.0201 *$ \\
\hline$\sigma_{s p f g d p, t}^{2}$ & $-0.0034^{*}$ & - & - & - & - & - & $0.0095^{*}$ & - & - & - & - & - \\
\hline$\sigma_{s p f g d p, t-1}^{2}$ & -0.0001 & - & - & - & - & - & -0.0039 & - & - & - & - & - \\
\hline$\sigma_{\text {spfind }, t}^{2}$ & - & $-0.0029^{*}$ & - & - & - & - & - & 0.0052 & - & - & - & - \\
\hline$\sigma_{\text {spfind }, t-1}^{2}$ & - & -0.0001 & - & - & - & - & - & -0.0067 & - & - & - & - \\
\hline$\sigma_{g d p, t}^{2}$ & - & - & $-0.0048^{*}$ & - & - & - & - & - & $0.0179^{*}$ & - & - & - \\
\hline$\sigma_{g d p, t-1}^{2}$ & - & - & 0.0019 & - & - & - & - & - & -0.0038 & - & - & - \\
\hline$\sigma_{\text {infl,t }}^{2}$ & - & - & - & $-0.0032^{*}$ & - & - & - & - & - & 0.0030 & - & - \\
\hline$\sigma_{\text {infl,t-1 }}^{2}$ & - & - & - & 0.0010 & - & - & - & - & - & -0.0035 & - & - \\
\hline$\sigma_{s p 500, t}^{2}$ & - & - & - & - & $-0.0009 *$ & - & - & - & - & - & 0.0001 & - \\
\hline$\sigma_{s p 500, t-1}^{2}$ & - & - & - & - & -0.0002 & - & - & - & - & - & $-0.0037 *$ & - \\
\hline$\overline{\sigma_{\text {fuel }, t}^{2}}$ & - & - & - & - & - & -0.0018 & - & - & - & - & - & $-0.0091^{*}$ \\
\hline$\sigma_{\text {fuel }, t-1}^{2}$ & & - & - & - & - & 0.0004 & - & - & - & - & - & -0.0056 \\
\hline
\end{tabular}

Notes:

1.The reported numbers above measure the effect of a one-standard-deviation increase in the relevant independent variable on growth of employment by size category. See section 7.2 for details.

2. An asterisk denotes that the estimated effect is significant at least at the $10 \%$ level (see notes to tables 2 and 3 ).

3. To keep the tables more compact, the effects of lagged dependent variable are not reported. For each specification's regression statistics $\left(\bar{R}^{2}\right.$ and $\left.\rho\right)$, see tables 2 and 3 . 
Table 5.2. Growth of number of businesses specifications
Dependent variable: FIRMS

Quantitative effect of one-s.d. increase in driving variable

\begin{tabular}{|c|c|c|c|c|c|c|c|c|c|c|c|c|}
\hline & \multicolumn{6}{|c|}{$\begin{array}{l}\text { Size Group: Small }(<500 \text { Employee) Businesses } \\
\text { Mean growth of number of businesses }=0.0066\end{array}$} & \multicolumn{6}{|c|}{$\begin{array}{l}\text { Size Group: Small }(<20 \text { Employee) Businesses } \\
\text { Mean growth of number of businesses }=0.0068\end{array}$} \\
\hline & S1 & S2 & S3 & S4 & S5 & S6 & S1 & S2 & S3 & S4 & S5 & S6 \\
\hline$G D P_{t}$ & $0.0060^{*}$ & $0.0074 *$ & $0.0055^{*}$ & $0.0067^{*}$ & $0.0064 *$ & 0.0066 & $0.0049^{*}$ & $0.0068^{*}$ & $0.0047^{*}$ & $0.0062^{*}$ & $0.0068^{*}$ & $0.0067 *$ \\
\hline$G D P_{t-1}$ & -0.0022 & $-0.0038^{*}$ & -0.0023 & $-0.0047 *$ & $-0.0027 *$ & -0.0024 & -0.0019 & $-0.0037^{*}$ & -0.0019 & $-0.0044 *$ & $-0.0034 *$ & $-0.0031^{*}$ \\
\hline$\sigma_{s p f g d p, t}^{2}$ & $-0.0034 *$ & - & - & - & - & - & $-0.0042 *$ & - & - & - & - & - \\
\hline$\sigma_{s p f g d p, t-1}^{2}$ & -0.0001 & - & - & - & - & - & 0.0007 & - & - & - & - & - \\
\hline$\sigma_{\text {spfind }, t}^{2}$ & - & $-0.0029 *$ & - & - & - & - & - & $-0.0029 *$ & - & - & - & - \\
\hline$\sigma_{\text {spfind }, t-1}^{2}$ & - & -0.0001 & - & - & - & - & - & -0.0003 & - & - & - & - \\
\hline$\sigma_{g d p, t}^{2}$ & - & - & $-0.0048 *$ & - & - & - & - & - & $-0.0052^{*}$ & - & - & - \\
\hline$\sigma_{g d p, t-1}^{2}$ & - & - & 0.0021 & - & - & - & - & - & 0.0023 & - & - & - \\
\hline$\sigma_{\text {infl }, t}^{2}$ & - & - & - & $-0.0032 *$ & - & - & - & - & - & $-0.0033^{*}$ & - & - \\
\hline$\sigma_{\text {infl,t-1 }}^{2}$ & - & - & - & 0.0010 & - & - & - & - & - & 0.0003 & - & - \\
\hline$\sigma_{s p 500, t}^{2}$ & - & - & - & - & $-0.0009^{*}$ & - & - & - & - & - & -0.0005 & - \\
\hline$\sigma_{s p 500, t-1}^{2}$ & - & - & - & - & -0.0002 & - & - & - & - & - & -0.0007 & - \\
\hline$\sigma_{\text {fuel, }, t}^{2}$ & - & - & - & - & - & -0.0017 & - & - & - & - & - & -0.0009 \\
\hline$\sigma_{\text {fuel }, t-1}^{2}$ & & - & - & - & - & 0.0005 & - & - & - & - & - & 0.0001 \\
\hline
\end{tabular}

Notes:

$\frac{\text { Notes: }}{1 . T h e}$ reported numbers above measure the effect of a one-standard-deviation increase in the relevant independent variable on growth of employment by size category. See section 7.2 for details.

2. An asterisk denotes that the estimated effect is significant at least at the $10 \%$ level (see notes to tables 2 and 3 ).

3. To keep the tables more compact, the effects of lagged dependent variable are not reported. For each specification's regression statistics $\left(\bar{R}^{2}\right.$ and $\left.\rho\right)$, see tables 2 and 3 . 


\begin{tabular}{|c|c|c|c|c|c|c|c|c|}
\hline Size & $\sigma_{s p f g d p}^{2}$ & $\sigma_{\text {spfind }}^{2}$ & $\sigma_{g d p}^{2}$ & $\sigma_{i n f l}^{2}$ & $\sigma_{s p 500}^{2}$ & $\sigma_{\text {fuel }}^{2}$ & $\overline{\sigma^{2}}$ & $\overline{\overline{G D P}}$ \\
\hline $\begin{array}{l}\text { All } \\
\bar{E}=0.0110\end{array}$ & 0 & 0 & $-0.0040^{*}$ & $-0.0043^{*}$ & $-0.0015^{*}$ & $-0.0058^{*}$ & -0.0026 & 0.0255 \\
\hline $\begin{array}{l}\text { Large }(>500) \\
\bar{E}=0.0161\end{array}$ & 0 & 0 & 0 & $-0.0033^{*}$ & 0 & $-0.0039 *$ & -0.0012 & 0.0225 \\
\hline $\begin{array}{l}\text { Small }(<500) \\
\bar{E}=0.0063\end{array}$ & $-0.0051^{*}$ & $-0.0078^{*}$ & $-0.0074^{*}$ & $-0.0045^{*}$ & $-0.0021^{*}$ & $-0.0058^{*}$ & -0.0055 & 0.0230 \\
\hline $\begin{array}{l}\text { Smaller }(<20) \\
\bar{E}=0.0053\end{array}$ & $-0.0083^{*}$ & $-0.0058^{*}$ & $-0.0033^{*}$ & 0 & $-0.0012^{*}$ & $-0.0041^{*}$ & -0.0037 & 0.0075 \\
\hline
\end{tabular}

Notes:

1. From tables 4.1 and 4.2 , we take the sum of the significant coefficients of each effect (e.g., $\sigma_{s p f g d p}^{2}$ ); these are the reported numbers above in each cell. If a particular coefficient is not statistically significant at the $10 \%$ level, we impute a value of zero for the above table.

2. $\bar{E}$ is mean growth (annual percentage change) of employment, by size category.

3. The term $\overline{\sigma^{2}}$ is the average uncertainty effect, across the different measures. The term $\overline{G D P}$ is the average GDP effect, across the different specifications.

\begin{tabular}{|c|c|c|c|c|c|c|c|c|}
\hline Size & $\sigma_{s p f g d p}^{2}$ & $\sigma_{\text {spfind }}^{2}$ & $\sigma_{g d p}^{2}$ & $\sigma_{i n f l}^{2}$ & $\sigma_{s p 500}^{2}$ & $\sigma_{\text {fuel }}^{2}$ & $\overline{\sigma^{2}}$ & $\overline{G D P}$ \\
\hline $\begin{array}{l}\text { All } \\
\bar{F}=0.0066\end{array}$ & $-0.0034^{*}$ & $-0.0029 *$ & $-0.0048^{*}$ & $-0.0032 *$ & $-0.0009^{*}$ & 0 & -0.0025 & 0.0065 \\
\hline $\begin{array}{l}\text { Large }(>500) \\
\bar{F}=0.0122\end{array}$ & $0.0095^{*}$ & 0 & $0.0179 *$ & 0 & $-0.0037 *$ & $-0.0091 *$ & 0.0024 & 0.0240 \\
\hline $\begin{array}{l}\text { Small }(<500) \\
\bar{F}=0.0066\end{array}$ & $-0.0034^{*}$ & $-0.0029^{*}$ & $-0.0048^{*}$ & $-0.0032 *$ & $-0.0009^{*}$ & 0 & -0.0025 & 0.0095 \\
\hline $\begin{array}{l}\text { Smaller }(<20) \\
\bar{F}=0.0068\end{array}$ & $-0.0042 *$ & $-0.0029^{*}$ & $-0.0052 *$ & $-0.0033^{*}$ & 0 & 0 & -0.0026 & 0.0098 \\
\hline
\end{tabular}

Notes:

1. From tables 5.1 and 5.2, we take the sum of the significant coefficients of each effect (e.g., $\left.\sigma_{s p f g d p}^{2}\right)$; these are the reported numbers above in each cell. If a particular coefficient is not statistically significant at the $10 \%$ level, we impute a value of zero for the above table.

2. $\bar{F}$ is mean growth (annual percentage change) of number of businesses, by size category.

3. The term $\overline{\sigma^{2}}$ is the average uncertainty effect, across the different measures. The term $\overline{G D P}$ is the average GDP effect, across the different specifications. 